\title{
HISTORIC PRESERVATION APPROACHES FOR THE CITY OF ARROYO GRANDE
}

\author{
A Professional Project \\ presented to \\ the Faculty of California Polytechnic State University, \\ San Luis Obispo
}

In Partial Fulfillment

of the Requirements for the Degree

Master City and Regional Planning

by

Rachel Elizabeth Grothe

June 2014 
(C) 2014

Rachel Elizabeth Grothe

ALL RIGHTS RESERVED 
TITLE:

AUTHOR:

DATE SUBMITTED:

COMMITTEE CHAIR:

COMMITTEE MEMBER:

COMMITTEE MEMBER:
Historic Preservation Approaches for the City of Arroyo Grande

Rachel Elizabeth Grothe

June 2014

Kelly Main, PhD

Assistant Professor City and Regional Planning

Chris Wm. Clark, JD

Lecturer, City and Regional Planning

Matthew Downing, MCRP

Assistant Planner, City of Arroyo Grande 


\author{
ABSTRACT \\ Historic Preservation Approaches for the City of Arroyo Grande \\ Rachel Elizabeth Grothe
}

Historic buildings represent a significant portion of the built environment. Local governments are at the forefront for deciding how these historic buildings will be treated and preserved. The preservation of historic buildings is important for a variety of reasons. Among these reasons is that the preservation of historic buildings and structures helps communities retain a sense of character and place. Additionally, historic preservation makes sense both economically and environmentally. The dilemma for many local municipalities, the City of Arroyo Grande in particular, is that historic structures are at risk of demolition and inappropriate alterations. Through a multi-modal approach, this project seeks to find ways that structures can be preserved. The project looks at how the federal, state and local governments deal with historic properties. It then provides information on how local governments can protect their historic resources through surveys, ordinances and design guidelines. The project relies heavily on the expert knowledge of the Secretary of the Interior and other best practice methods found during a review of the literature. The project serves to inform the Preservation Approaches Plan document for the City of Arroyo Grande which is Appendix 1. The Preservation Plan document serves as a roadmap for future public preservation activities. 


\section{ACKNOWLEDGMENTS}

This document would not have been possible without the support of my wonderful family. Words cannot express how thankful and grateful I am for putting up with me during the process of this project. A heartfelt thank you to my Committee members; Kelly, Chris and Matt. Kelly, thank you for all your guidance and support during one of the most transformative experiences of my life. Chris, thank you for your words of encouragement and support over my second year. Matt, thank you for agreeing to sit on my Committee, your invaluable input and insight and for being such a great office mate. This experience has not been easy and the growing pains have been many. But despite the many ups and downs I am thankful for the experience. I have grown in so many ways (professionally, academically, emotionally and mentally) and accomplished more than I ever imagined. 


\section{TABLE OF CONTENTS}

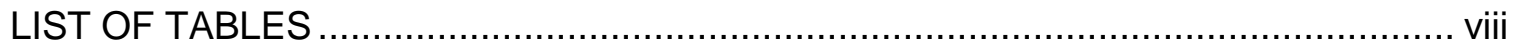

CHAPTER 1: INTRODUCTION ....................................................................... 1

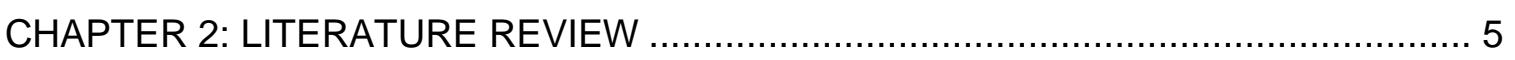

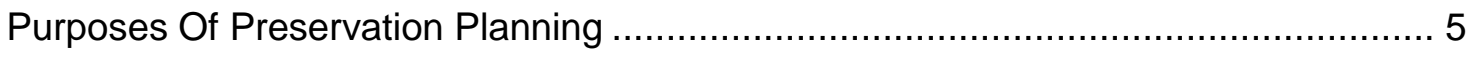

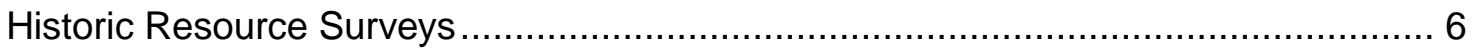

Preserving The Historic Building Stock: Historic Preservation Ordinances ................11

Guidelines For The Treatment Of Historic Structures ..........................................16

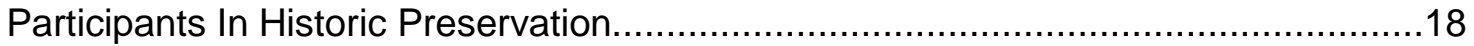

Historic property owners ...............................................................................

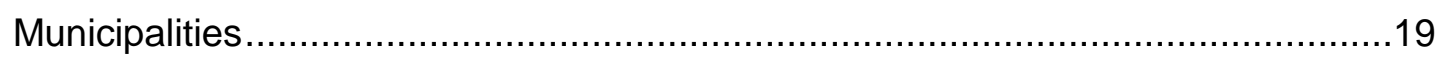

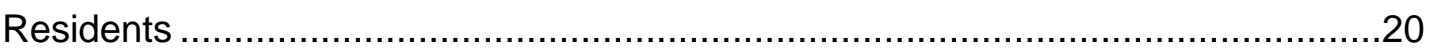

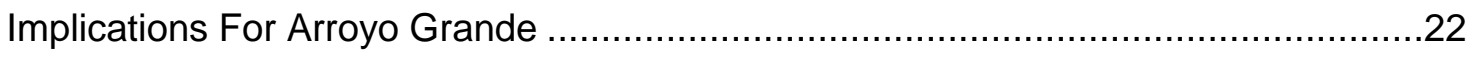

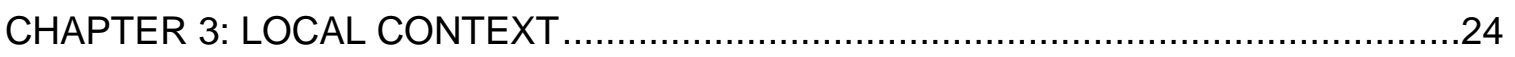

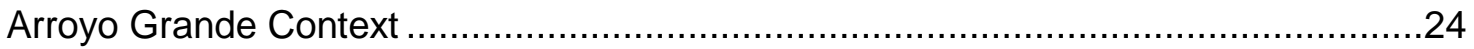

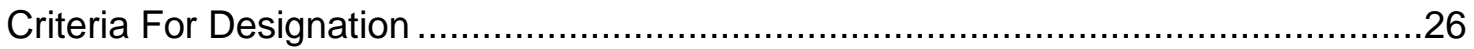

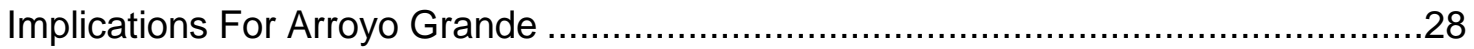

CHAPTER 4: PAST AND CURRENT PRESEVATION EFFORTS .............................29

Design Guidelines And Standards For The Historic Overlay District........................30

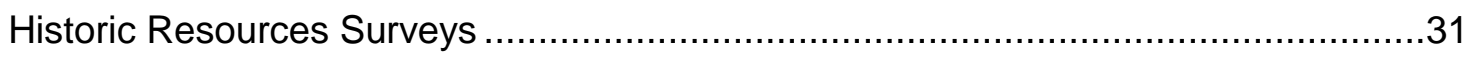

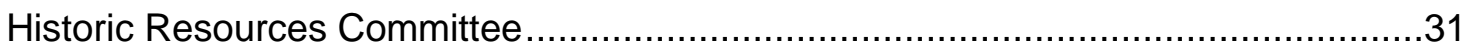

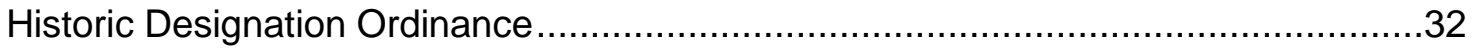

Historic Context Statement ............................................................................

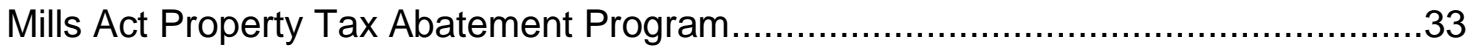

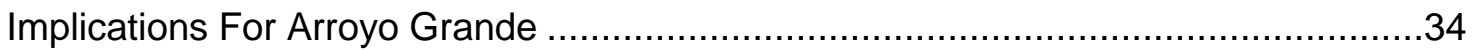

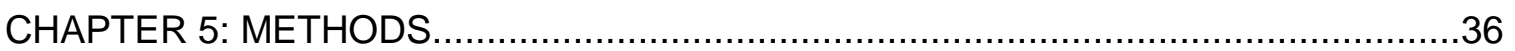

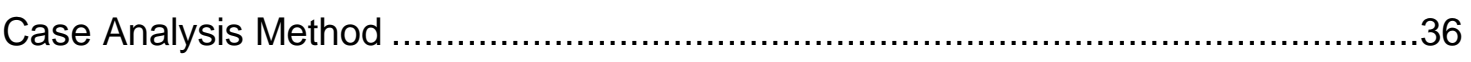

Case Analysis: City Of San Antonio Strategic Historic Preservation Plan..................37

Case Analysis: City Of Anaheim Preservation Plan.............................................39

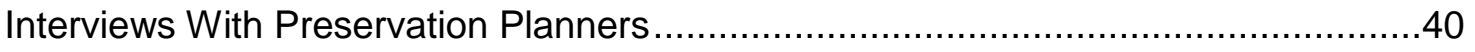

Interviews With Historic Resources Committee ....................................................43

Local Document Review ............................................................................. 44

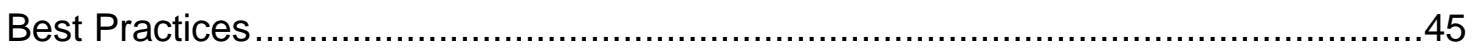


CHAPTER 6: FINDINGS FOR ARROYO GRANDE'S PRESERVATION APPROACH ..46

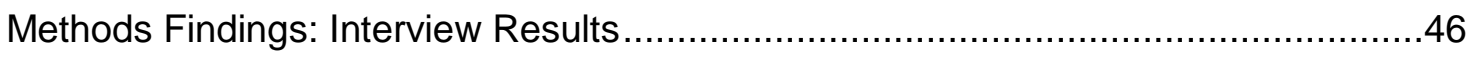

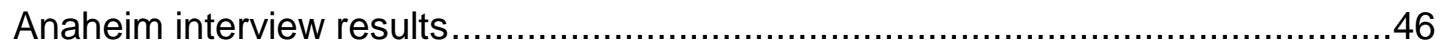

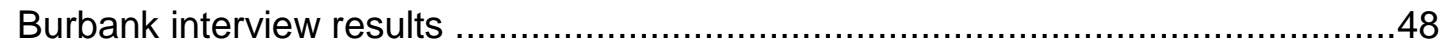

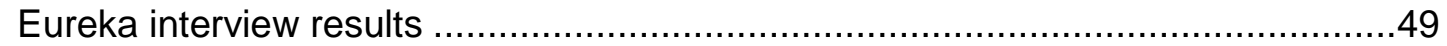

Historic Resources Committee interview results .............................................50

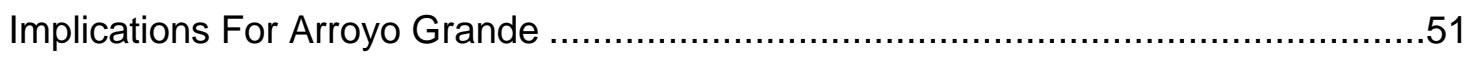

Best Practices And Literature Review Findings ...............................................52

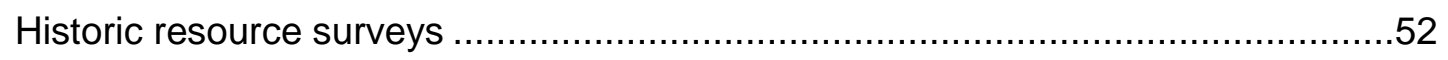

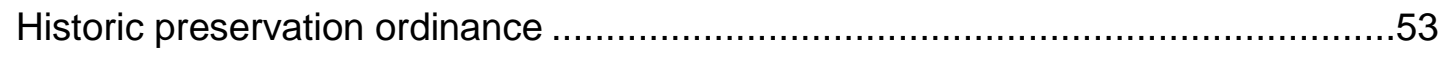

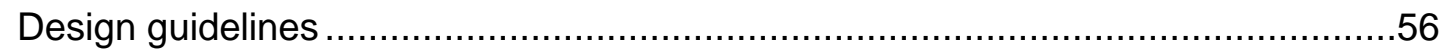

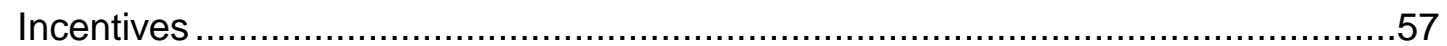

Components yet to be implemented into Arroyo Grande's preservation program ........58

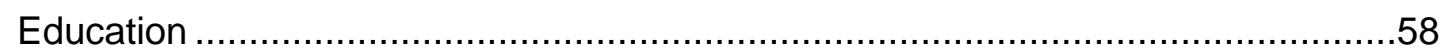

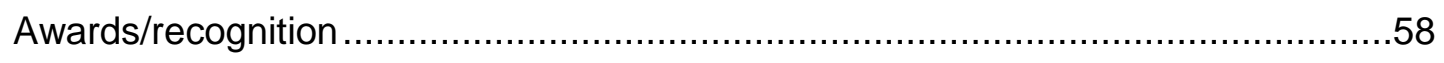

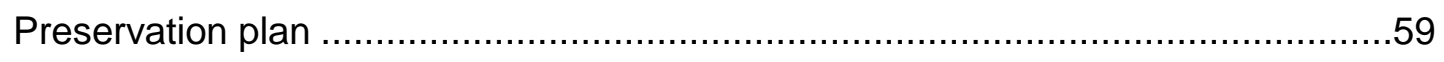

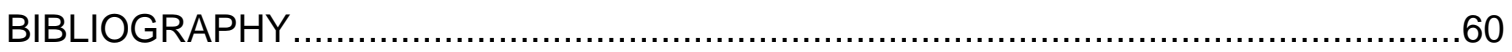

APPENDIX 1: HISTORIC PRESERVATION PLAN FOR ARROYO GRANDE ...............62 


\section{LIST OF TABLES}

Table

Page

1. Case Analysis Criteria ..................................... 37 


\section{CHAPTER 1: INTRODUCTION}

The preservation of historic resources is vital to cities for number of reasons. This project seeks to explore some of these reasons with the intent of identifying best practices information to assist the City of Arroyo Grande in strengthening their preservation approach. As cities continue to grow, local governments are in a unique position to facilitate the preservation of valuable historic resources. Local municipalities are on the front lines and as buildings age, cities are faced with how they should be addressed. Planners and city officials have an obligation to citizens, future citizens and even society as a whole to preserve the past. Historic preservation is of particular relevance to planning in that it creates many benefits that extend beyond the physical preservation of buildings. If done right, the preservation of historic resources can have a positive ripple effect and work as a part of city planning to create cities that are memorable, vibrant and economically sound.

Historic preservation is an endeavor that seeks to conserve and preserve buildings, structures and other landmarks. Buildings do not have to be "old" to be preserved but generally are. Sometimes newer buildings or buildings less than 50 years of age are preserved if they are associated with a notable individual or event. Preservation activities can be carried out by individuals, cities, counties, states, nations and private organizations.

For the purposes of this project, I will be referring to preservation activities facilitated by local, state and national agencies, with a main focus on the local 
level. Additionally, this project will frequently use the term 'preservation program'. A preservation program is the toolkit of approaches that municipalities utilize to carry out preservation work. According to the National Park Service, a complete preservation program includes seven different yet inter-related and dependent components: 1) historic resource surveys, 2) historic preservation ordinance, 3) design guidelines, 4) incentives, 5) education programs, 6) preservation plan, and 7) recognition/awards. This project will discuss each of these topics but will explore in an in-depth manner historic resource surveys, ordinances and guidelines.

Historic preservation can have different meanings depending on who is involved. This is because there are private agencies and public agencies (national, state and local) that take on preservation activities. Also, this is because there is a category of historical significance as the local level, which allows for communities to define their own meaning. As such, each of these agencies has different definitions and criteria as to what is considered historic. For the purposes of this project, the term 'historic' will be referring to a resource that has been designated on the local, state or national level. Other resources that do possess historical merit but have not been designated will be referred to as 'potential historic resources'.

Within the field of historic preservation there are three levels of government, all of which possess distinct roles. Historic preservation on a national scale is facilitated by the Federal Government. 
The federal role is to fund activities, set an overall superstructure of preservation activities, and to ensure consistency of the approach from states to state, the federal government also monitors its own properties and activities and provide incentives to encourage appropriate work at historic buildings. But it has virtually no regulatory power over owners of historic properties (Ligibel and Tyler, 2009, p. 58).

The state is different from the federal government in that they administer preservation programs directly to the local governments.

At the state level, State Historic Preservation Offices (SHPO) encourage surveys of significant historic resources and facilitate federal activities, providing a link between the federal and local levels of government and state laws authorized for local programs. But state preservation officials also have limited regulatory powers over historic properties (Ligibel and Tyler, 2009, p. 58).

Real protective power of historic preservation is found at the local level. Only at the local level can historic properties be regulated and protected through local ordinances. These local ordinances are administered through the local community by either an appointed or elected board of residents.

"The National Historic Preservation Act of 1966 enabled local governments to establish such review agencies. These powers are reserved for local governments because of the underlying philosophy that each community should determine for itself what is historically significant, what is of value to the community, and what steps should be taken to provide protection" (Ligibel and Tyler, 2009, p 59).

This is why historic preservation on a local level is so vital for the cities of today.

Cities have the power to create ordinances, establish review commissions, conduct surveys, designate structures and dictate appropriate methods of intervention. It is this regulatory power that makes up a city's historic preservation program. 
The purpose of this project is to provide a base for understanding the types of historic preservation approaches currently being utilized by local governments. Chapter two discusses some best practice methods in the field of preservation and provides background information in the form of a literature review on the topic of historic preservation. Chapter three provides the local context on Arroyo Grande. Chapter four provides a discussion on the past and current preservation approaches of Arroyo Grande. Chapter five lays out the research methods used in this project. Research methods for the project include a case analysis, interviews, local document review, review of government publications and other scholarly articles on the topic of preservation. A wide variety of methods was chosen to provide a broad overview on not only the topic of historic preservation but of the local context of Arroyo Grande as well. Chapter six discusses the findings and implications for Arroyo Grande based on the information laid out in the previous chapters. Finally, this project will serve to inform the Historic Preservation Approaches Plan document for the City of Arroyo Grande which is Attachment One of this document. 


\section{CHAPTER 2: LITERATURE REVIEW}

In order to begin offering suggestions and critiques on historic preservation approaches for Arroyo Grande, a basic understanding of some of the best practice methods must be researched and explored. This information is gathered from two types of sources, scholarly and practice based. The following review of the literature discusses the purpose of preservation planning which segways into a discussion of three best practice approaches in the field of historic preservation; historic resource surveys, historic preservation ordinances and guidelines for the treatment of historic structures. Additionally, the chapter provides a discussion on the participants in preservation planning; property owners, municipalities and residents. The chapter concludes with a list of the implications for Arroyo Grande.

\section{Purposes Of Preservation Planning}

While it is important to discuss and explore the various benefits for historic preservation, it is also equally important to have an understanding of the purposes of preservation planning. One approach to preservation planning is the creation of a preservation plan. "A preservation plan is a proactive means of planning for the preservation and protection of a community's character and historic resources" (White and Roddewig, 1994, p. 1). It is important to note that a preservation plan provides the foundation for development of a preservation program, and helps to resolve existing and future conflicts between competing land-use goals. Below is a list of reasons for preservation planning as published by the National Park Service and the American Planning Association: 
1. To state clearly the goals of historic preservation in the community,

2. To comply with state zoning or planning-enabling legislation requiring local governments to have comprehensive plans and requiring that there be a mandatory or optional historic preservation element in that plan,

3. To let current and future property owners and residents know in advance how the community intends to grow and what the community wants to protect,

4. To help provide a legal defense against lawsuits alleging unfair treatment of property owners or arbitrary decisions by government,

5. To eliminate uncertainty or confusion about the purpose, meaning, and content of an existing local historic preservation ordinance,

6. To form the basis for adoption of a new historic preservation ordinance or to strengthen the legal basis of an existing historic preservation ordinance,

7. To ensure consistency, or eliminate inconsistency, between various local government policies that affect the community's historic resources,

8. To educate and inform citizens about their heritage and its value to the community,

9. To create an agenda for future preservation activities and to create a way to measure progress in protecting historic resources,

10. To provide a basis for interim protection of historic resources while steps are taken to adopt a formal preservation ordinance to protect those resources,

11. To comprehensively address issues relating to tourism, zoning, traffic patterns, development patterns, and design that affects historic resources,

12. To encourage economic development through the preservation of historic resources,

13. To strengthen the political understanding of and support for historic preservation policies.

(White and Roddewig, 1994, pgs. 1-2).

\section{Historic Resource Surveys}

Conducting a historic resource survey is an integral part of a community's preservation program. In fact, surveys should be conducted before any structure can be designated as a historic resource. This is to ensure that all potential landmarks and all potential historic districts are eventually considered for designation (White and Roddewig, 1994, p. 9). This is important from a legal 
standpoint as it "guards against singling out some owners of historic structures for designation while other owners with properties as equally as meritorious under criteria adopted by a community for designation of landmarks or historic districts escape consideration" (White and Roddewig, 1994, p. 7). As previously discussed, within the preservation program is the preservation plan. The preservation plan provides a process for ensuring that all potential resources are considered for designation. The survey is the method for identifying and gathering data on a community's historic resources.

The Secretary of the Interior is a nationally recognized entity which falls under the umbrella of the National Park Service. They are charged with providing a variety of resources, information and standards on historic preservation. "The National Park Service was established in 1916 within the U.S. Department of the Interior as the administrative agency responsible for national parks" (Ligibel and Tyler, 2009, p.32). Over time, "the National Park Service also developed standards and guidelines used for historic rehabilitation projects that have become the standard used nationally" (Ligibel and Tyler, 2009, p. 33). Another area of expertise is historic resource surveys. According to the National Park Service,

a survey includes a field survey, the physical search for and recording of historic resources on the ground, and planning and background research before the survey begins. It also includes an organization and presentation of survey data as the survey proceeds, and the development of inventories (White and Roddewig, 1994, p. 8).

Inventories are one of the basic results from a survey. They are a way to organize information on the evaluated properties that have been deemed 
significant. Another component to the inventory is the actual evaluation. This is the process of paring the survey data to produce the inventory and requires determining whether identified properties meet the defined criteria of historical, architectural, archaeological, or cultural significance (White and Roddewig, 1994, p. 10).

Surveys are one of the components to a complete historic preservation program and play a vital role in the preservation of resources. Surveys provide a community with a specific universe of historic resources and a focus for the implementation of the goals and objectives of the preservation plan. It is important the surveys are updated on a regular basis in order to document any changes and to add any additional buildings that become more important over time. The survey also serves as an educational method for the community at large.

The National Park Service published a best practice guide to conducting surveys. The guide provides information regarding preparation, types of surveys, and qualified survey proctors. Preparation for the survey involves four major steps: 1) Planning the survey, 2) Conducting the survey, 3) Review and organization of survey data, and 4) Use of survey data in planning (White and Roddewig, 1994, p. 10). Planning of the survey is important because it takes into account the specific needs of the community. Answering questions specific to the community such as

will the survey be used as the basis for designation of individual buildings and structures or districts or will it be used to identify possible resources 
for planning purposes, with more detailed information compiled at some later date for purposes of designation? (White and Roddewig, 1994, p. 8).

There are two levels of surveys, reconnaissance and intensive surveys. The reconnaissance survey is a 'once over survey' and serves as a good starting point for how future more detailed surveys should be conducted. The intensive survey, like its name suggests, provides a closer and more detailed look at the survey area.

The type of survey completed depends on the needs of the community. Either type of a survey may form the basis of a preservation planning effort. A reconnaissance survey should be undertaken under most circumstances to provide the basis for further intensive research (White and Roddewig, 1994, p. 9).

When conducting a survey, it is important to pay attention to the historical context of a city. "Historic contexts are developed on the basis of background data on the community's history and prehistory, or on such data from the surrounding area" (Guidelines for Local Surveys, 1985, p. 15). Furthermore, it is vital to know and heed the community's values. This requires community involvement. In addition to providing valuable local knowledge of historic resources that may be unknown, engaging the community offers them the chance to contribute, which makes them feel heard and valued.

In addition to the reconnaissance and intensive surveys there are four organizing approaches to ensure that all potential historic buildings will eventually be considered for designation according to the criteria contained in the community's preservation ordinance or preservation plan.

- Systematic approach: Schedule consideration by reference to discrete geographic areas or political districts of the city (e.g., north side first, then 
the south side, etc., of first ward, second ward, etc.) that will be considered.

- Timeline approach: Schedule consideration of structures or districts in order of age (e.g., survey the city for all remaining structures that pre-date some critical event or date - like pre-Civil War structures in southern cities, pre-fire or pre-flood structures in other communities - and then consider structures from the next appropriate era or period).

- Stylistic/thematic: Schedule consideration of structures by style or theme (e.g., first survey for all Prairie style, Federalist, Beaux Arts, pioneer settlement, Civil War era, early Industrial Revolution, structures or sites, then systematically survey for other significant styles or themes.

- Crisis approach: Schedule consideration by reference to the strength of the threat to selected historic resources. Consider the most endangered structures first, which might mean consideration of that part of the city experiencing the most demolition or neglect.

(White and Roddewig, 1994, p. 9).

The National Park Service has survey forms available for downloading from their website. Surveys can be done by lay people but the Department of the Interior recommends that professionals such as architectural historians, historians, archeologists and architects conduct the surveys. If this is not possible, then a professional should at least oversee those that are conducting the surveys. Training can be offered to interested community members who can act as a wonderful attribute to the survey process by bringing down the high costs of retaining a team of professionals.

Surveys are extremely important to the preservation process as it is the starting point in which potential historic resources are identified and protected. While it is important to be proactive and create a schedule, it is also equally important to be open to receiving information from the public regarding potential historic resources. "A community should be both proactive and reactive, it should have 
both a program for identifying and considering potential landmarks and districts as well as one for reacting to nominations brought forth by others" (White, 1994, p. 9). Another reason surveys are an integral part of the preservation process is because they:

guard against singling out some owners of historic structures for designation while other owners with properties equally meritorious under criteria adopted by a community for designation of landmarks or historic districts escape consideration. Courts may call that a violation of the fundamental American legal principles of 'due process' and 'equal protection of the law (White, 1994, p. 7).

It is the preservation plan that provides the process and policies for the preservation of historic resources, but it is the survey and data collected that provides the basis for what structures actually get preserved.

\section{Preserving The Historic Building Stock: Historic Preservation Ordinances}

As previously stated, preservation is practiced on the three levels of government: national, state and local. Each of the three governments offer varying forms and degrees of protection. The national designation offers by far the least protection of historic resources.

If a project is not subject to CEQA, to local preservation ordinances, or to other environmental regulations, owners are free to make changes to their property. It is possible that the property could be so altered, however, that it would be removed from the Register (National Register of Historic Places Fact Sheet, ohp.parks.ca.gov).

The State of California, like the National Register is almost equally as lenient.

The real power and best practices lie within ordinances at the local government level. However, "a preservation ordinance will only be as effective as the power 
and willingness of the community to enforce it" (Drafting Historic Preservation Ordinances, OHP Technical Assistance Bulletin \#14, 2005, p. 79).

State Historian Lucinda Woodward can speak to the importance of having a local ordinance in place to protect historic properties. Woodward is an expert in local preservation ordinances. "The historic preservation ordinance provides the regulatory and legal framework for protecting historic properties and integrating preservation with other decision making at the local level of government" (Woodward, 2010, p. 4).

The basic preservation ordinance should contain the following sections:

- Purpose: This section should discuss why a community wants to preserve and what it hopes to accomplish.

- Enabling Authority: This section discusses the legal authority of regulating historic buildings and areas.

- Establishment of the Preservation Commission: A local commission must be identified in order to make decisions and recommendations regarding historic structures. It is in this section that the ordinance identifies committee qualifications and committee decision-making authority.

- Procedures and Criteria for Designating Historical Resources: This section set forth the criteria that potentially historic must meet in order to be considered historic. This section should also clearly indicate the types of resources it seeks to protect (individual structures, districts, archaeological). 
- Procedures and Criteria for Actions Subject to Review: This section details how historic structures are dealt with in terms of alterations and demolitions.

- Consideration of Economic Effects: Ensures compliance with federal and state requirements that allows the property owner to make a case that enforcement of the ordinance will cause hardship

- Appeals: This section dictates how appeals are made and who they are made to.

- Enforcement: This section dictates how strong an ordinance is and lays out the fines (it any) should a property owner decide to alter or demolish a historic structure without permission.

- Definitions : Clear definitions help to establish the scope of regulation. This allows for a clear understanding of the type of structures and other features subject to review.

(Drafting Historic Preservation Ordinances, OHP Technical Assistance Bulletin $\# 14,2005$, Table of Contents).

The Office of Historic Preservation provides a technical manual for local governments that covers how to write effective historic preservation ordinances. This is the go-to manual that local governments all over California utilize when writing or updating their own ordinances. The manual provides a simple and clear process that municipalities can follow in order to produce an effective ordinance that is tailored to their individual needs. One component of an effective ordinance is enforcement. Preserving historic structures is done effectively by enforcement. 
The enforcement section of an ordinance is where noncompliance, maintenance and upkeep requirements are discussed. "The challenge in drafting effective enforcement provisions is to craft remedies strong enough to deter violations and induce compliance, but not so draconian that courts shy away from imposing them"(Drafting Historic Preservation Ordinances, OHP Technical Assistance Bulletin \#14, 2005, p. 80). Fines are one such way to encourage compliance with an ordinance. However, they should be based on the degree of the offense as a fine of $\$ 300$ may not be enough to deter a developer from demolition.

The primary goal of an enforcement provision should be to secure compliance with the local preservation law and to protect historical resources, not to punish offenders. Thus, while fines may be necessary to deter future violations, the preservation ordinance should vest the local government with power to seek injunctive relief to, for example, put an immediate stop to an illegal demolition (Drafting Historic Preservation Ordinances, OHP Technical Assistance Bulletin \#14, 2005, p. 80).

Should it be necessary due to an owners ignoring an administrative compliance order, the local government should have the ability to obtain a judicial decree to enter the property, make necessary repairs and then place a lien on the property. The local government can then request repayment before the property is sold. Another best practice the document suggests is forcing reconstruction. This can be used as a remedy when a historic resource or part of it has been destroyed. Another approach local governments are encouraged to include is provisions within their ordinance that require removal or modification of any new construction within historic districts where the new construction would adversely impact the historic character of the district. 
Should an illegal demolition occur, the OHP offers this best practice method: loss of further entitlement. This would restrict future building and development entitlements on a property where a preservation violation has taken place. Depending on a community's level of commitment to preservation, development rights can be restricted from five to twenty years. This restriction is usually limited to the floor-area-ratio (FAR) and does not allow future development to exceed the FAR of the demolished structure for a certain number of years.

Best practices for maintenance of historic structures tread a fine line between being overly punitive and too lenient. This depends on individual community values and how the community feels about historic preservation. Therefore, enforcement of maintenance will vary from community to community. Communities should be careful that their ordinance not demand a permit for minor repairs or routine maintenance. The danger with an overly punitive ordinance is that repairs will not get done, will get done but without a permit and can result in little political support. However, if the language in the ordinance is not strong enough or weakly defined, local governments run the risk of poorly maintained properties. Drafting Effective Historic Preservation Ordinances cites the City of Fresno as having a model minimum maintenance provision and as a model for a general regulation prohibiting demolition by neglect. Fresno's ordinance is specific in its maintenance duties and states that historic structures should be kept in good repair and free from structural defects. It then goes on to stipulate that types of defects that shall be repaired. The list is comprehensive 
and includes foundations, walls, exterior plaster, roofs, flooring, chimneys and any fault that renders it structurally unsafe.

\section{Guidelines For The Treatment Of Historic Structures}

Guidelines should not be overlooked when considering historic structures.

Guidelines are what help ensure a historic structure does not lose its integrity.

Once again, the Secretary of the Interior offers best practice techniques that professionals may refer to when deciding an appropriate method of treatment.

The Secretary of the Interior provides technical assistance on the four treatment approaches. Treatment ranges from preservation, to rehabilitation, to restoration and finally reconstruction. Those looking at a historic structure must consider what needs to be accomplished and select from the treatments accordingly:

- Preservation: the act or process of applying measures to sustain the existing form, integrity, and material of a building structure, and the existing form and vegetative cover of a site. It may include initial stabilization work, where necessary, as well as ongoing maintenance of the historic building materials.

- Rehabilitation: the act or process of returning a property to a state of utility through repair or alteration which makes possible an efficient contemporary use while preserving those portions or features of the property which are significant to its historical, architectural, and cultural values.

- Restoration: the act or process of accurately recovering the form and details of a property and its setting as it appeared at a particular period of time by means of removal of later work or by the replacement of missing earlier work.

- Reconstruction: the act or process of reproducing by new construction the exact form and detail of a vanished building, structure, or object, or part thereof, as it appeared at a specific period of time.

(Murtagh, 1997, pgs. 19-20, 22) 
Each of the four approaches offers specific guidelines and standards on how a historic property should be treated. Standards are so detailed that they even provide guidelines for specific materials such as wood and brick.

Bernard Feilden also discusses the four approaches in his book Conservation of Historic Buildings. He states the objective of preservation is it to keep the structure in its existing state. This includes some routine maintenance and repairs to prevent decay. He goes on to discuss the second approach, rehabilitation. His discussion and understanding of this treatment differs greatly from that set forth by the Secretary of the Interior. He states that the best way to preserve a building is to keep it in use. The original use is ideal, but when this is not feasible, adaptive reuse provides an avenue in which historic buildings can be protected. The third approach of restoration is discussed by Feilden who states, "The object of restoration is to revive the original concept of legibility of the object. Restoration and re-integration of details and features occurs frequently and is based upon respect for original material, archaeological evidence, original design and authentic documents" (2003, p. 9). Feilden goes on to explain the importance of replacing missing parts with those that are complimentary yet distinguishable from the original so as not to falsify archaeological or historical evidence. The final approach is reconstruction. This approach should only be undertaken in times of disasters such as earthquakes, fire or war. "Reconstruction cannot have the patina of age. Reconstruction must be based upon accurate documentation and evidence, never upon conjecture" (Feilden, 2003, p. 12). 
While the four treatment approaches are important and vital to the protection of historic resources, one must not forget the value of maintenance. Historic structures should be maintained in such a way that prevents deterioration. The maintenance of a structure can ensure that none of the four approaches are required. "Prevention entails protecting cultural property by controlling its environment, thus preventing agents of decay and damage from becoming active. Neglect must also be prevented by sound maintenance procedures based on regular inspections" (Feilden 2003, p. 9).

\section{Participants In Historic Preservation}

\section{Historic property owners}

Historic property owners are in a unique position to be stewards of local history. But this stewardship can come at a price. While maintaining a historic home can sometimes be costly, it does come with some benefits which can help to offset some of the costs. If the home is located within a city that has historic preservation policies, chances are a permit may be required for alterations and demolitions. The oversight of the permit depends on how stringent the codified policies are and differs by municipality. It is important for property owners to know what the policies are so alterations are not made illegally. Often times property owners may be required to follow specific guidelines and standards when making any alterations on their property. This can sometimes be frustrating for one main reason: costs.

States and municipalities often condition incentives on compliance with certain standards. Common requirements include (1) adherence to the Department of the Interior's rehabilitation standards, (2) maintenance 
requirements that run with the land, (3) periodic inspections to ensure compliance, and (4) public-access requirements. Substantial penalties may be imposed if a homeowner fails to comply (Kohtz, 2012, p. 1045).

One way to offset some of the costs associated with the maintenance and upkeep of a historic building is through incentives. According to Preparing a Historic Preservation Plan, there are multiple incentives that municipalities can offer and differ from community to community.

They include property tax abatement, a property tax freeze, a property tax credit, tax-exempt bond financing, mortgage guarantees or credit enhancement, tax increment financing, relief from local sales taxes, local government acquisition and subsequent write-down of sale of historic resources for rehabilitation, direct loans or grants, and relief from zoning and building code regulations (White and Roddewig, 1994, p. 15).

\section{Municipalities}

Should a municipality decide to undertake preservation planning, they should be prepared in terms of staffing and political ramifications. Creating a complete and functioning preservation program requires substantial staff time and the right political climate. From a political standpoint, historic preservation can be a touchy subject because it deals with property rights. "Indeed, it only relatively recently that it has become acceptable (and constitutional) for government to its powers actively to safeguard the physical heritage" (Cullingworth, 1997, p. 137). Property rights allow owners to develop their property within the parameters of zoning. "This is particularly the case with the USA, where history and culture have produced constitutionally-protected property rights" (Cullingworth, 1997, p. 137). Implementing historic preservation policies creates more rules and regulations regarding what property owners can and cannot do with their properties. Therefore it is prudent for municipalities take the political temperature of their 
constituents to ascertain the general feeling towards historic preservation. Once it is decided that the preservation program will proceed, it is important that staff choose their language carefully and make sure to highlight all the benefits that historic preservation can bring to both individual property owners and the community as a whole.

In addition to the staffing and political ramifications of historic preservation policies, cities should consider how the incentives offered to residents will affect them.

Historic preservation incentives are not direct spending programs, but they still affect government revenues. Tax incentives for historic preservation are considered a 'tax expenditure'. Tax expenditures induce taxpayers to engage in a type of behavior the government wants to encourage, like historic preservation. As spending programs in disguise, tax incentives should be analyzed in spending terms. Preservation incentives can consume enormous amounts of potential tax revenue. The incentive should create the largest possible amount of benefits at the lowest possible cost (Kohtz, 2012, p. 1047).

The money lost in potential tax revenue from incentives offered to residents must be made up for elsewhere. This is where cities must weigh their options and figure out if the justifications and benefits of historic preservation outweigh the amount lost in tax revenue.

\section{Residents}

Living in a place that values historic resources can create a greater sense of place and community for all residents. Additionally, it creates and fosters a sense of pride among community members. The sense of history can help contribute to community pride, and to a better understanding of a community's present. In addition to helping to fight sprawl, historic preservation helps to preserve 
community identity and maintain connections to the past. "It has been said that, at its best, preservation engages the past in a conversation with the present over a mutual concern for the future" (Murtagh, 1997, p. 168). This concern for the future deals specifically with which historical resources should be saved. Historical resources are a physical link to the past and maintaining a connection is necessary in order to allow residents to "relate to past events and to rebel against the homogeneity found in the suburbs" (Wojno, 1991, p. 298).

Furthermore, historic preservation allows residents a unique educational opportunity that would otherwise be watered down by the written word.

Another way historic preservation can have an effect on residents is through an increased tax base through heritage tourism. The National Trust for Historic Preservation defines heritage tourism as, "'traveling to experience the places, artifacts and activities that authentically represent the stories and people of the past,' and heritage tourism can include cultural, historic and natural resources" (preservationnation.org). According to Preservation Nation, a national non-profit committed to historic preservation:

heritage tourism can be an attractive economic revitalization strategy, especially as studies have consistently shown that heritage travelers stay longer and spend more money than other kinds of travelers. As an added bonus, a good heritage tourism program improves the quality of life for residents as well as serving visitors (preservationnation.org).

This sentiment is backed up by scholarly literature as well. Researcher David Kohtz writes in the Texas Law Review that "various studies have confirmed that visitors attracted by a city's historic places stay longer and spend more money 
than others, providing an important boost to local economies" (Kohtz, 2012, p. 1045).

\section{Implications For Arroyo Grande}

The literature suggests that Arroyo Grande understand the purposes of preservation planning and improve their approach in three key areas: surveys, an ordinance and design guidelines.

- Purpose of preservation planning: Arroyo Grande must first understand that preservation planning is the basis for the development of a preservation program. The preservation program is what is needed in order to facilitate the programs that make preservation work.

- Surveys: If the City is interested in preserving more buildings, the first step is conducting surveys. The guidelines outlined in the literature provide the City with four survey types to choose from depending on their needs.

- Preservation ordinance: If the City wants to discourage inappropriate alterations they should consider including language in their ordinance that acts as a disincentive to inappropriate alterations.

- Design guidelines: Arroyo Grande could strengthen their current design guidelines by including language from the Secretary of the Interior that dictates how specific materials should be treated.

The literature also suggests that the players in preservation understand their roles: 
- Historic property owners: They play a significant role in making preservation work. Historic property owners in Arroyo Grande should do what they can to become educated on the incentives offered and identify which would be most beneficial to them.

- Municipalities: Arroyo Grande should be prepared to dedicate significant staff time to preservation activities. Additionally, since preservation can be politically charged, Arroyo Grande should be aware of the repercussions of proposing various preservation programs and should conduct outreach to gauge the political climate before committing to a preservation program. Additionally, staff should be prepared with an education program in order to disseminate information on the various preservation programs offered.

- Residents: Residents play a significant role in making preservation work. Additionally, Arroyo Grande residents are poised to reap the benefits of preservation through enhanced character and through the economic benefits of heritage tourism. 


\section{CHAPTER 3: LOCAL CONTEXT}

When thinking about historic preservation, potential resources must first be evaluated for historic significance before designation. Significance will vary by municipality but will be based on a historic context statement. This statement serves as the framework for the documentation and evaluation of historical resources. Without a context statement, a municipality is not able to fully evaluate its resources for significance. This chapter discusses the importance of context statements within historic preservation, Arroyo Grande's local context and the criteria for historic designation at the national, state and local levels. It concludes with a list of implications for Arroyo Grande.

Decisions about the identification, evaluation, registration and treatment of historic properties are most reliably made when the relationship of individual properties to other similar properties is understood. Information about historic properties representing aspects of history, architecture, archeology, engineering and culture must be collected and organized to define these relationships. This organizational framework is called a 'historic context'. The historic context organizes information based on a cultural theme and its geographical and chronological limits. Contexts describe the significant broad patterns of development in an area that may be represented by historic properties. The development of historic contexts is the foundation for decisions about identification, evaluation, registration and treatment of historic properties (nps.gov/historiccontexts).

\section{Arroyo Grande Context}

Currently, the City of Arroyo Grande has a historic context statement in place.

The context statement was adopted by the City Council in late 2011. It serves as a basis of systematic evaluation of the City's historic resources. Additionally, it also serves to inform future preservation planning efforts in the City. The context statement was fashioned after the guidelines set forth by the Office of Historic Preservation and includes sections on historical background, themes, property 
types, preservation goals and priorities and any appendices. Additionally, the document relies on other agencies and publications put forth by the Department of the Interior and the National Park Service.

One of the most significant sections is on the guidelines for evaluation. This is based on significant time periods and themes. In each time period, various themes took place and helped to grow the built environment in Arroyo Grande. The context statement identifies the following periods on important event and development trends:

- Pre-history and native people (pre-1772)

- Spanish and Mexican period (1773-1861)

- Village of Arroyo Grande (1862-1910)

- Incorporation of Arroyo Grande (1911-1939)

- World War II and post-war era (1940-1965)

- Modern Arroyo Grande (1966- present)

(Historic Context Statement and Survey Report, City of Arroyo Grande, 2013) The above time periods are explored and discussed in the context statement as they relate to the growth and evolution of the built environment in Arroyo Grande. The following themes are identified and explored:

- Agriculture and industry

- Transportation and infrastructure

- Commercial development 
- Residential development

- Civic and institutional development

- Ethnic and cultural diversity

Property types in Arroyo Grande can be classified into four categories:

- Residential

- Commercial

- Civic and institutional

- Agricultural

(Historic Context Statement and Survey Report, City of Arroyo Grande, 2013)

\section{Criteria For Designation}

The context statement provides information to Arroyo Grande on the three ways historic resources can be evaluated and then registered/designated. The first step in the registration/designation process is to determine if the property is of historical significance. In order to determine this, a set of evaluation criteria must be in place. The registering or designating of historic resources is done on three levels of government: federal, state and local. The federal government lists its criteria for designation on the Office for Historic Preservation (OHP) website. To be eligible for listing on the National Register, a resource must meet at least one of the following criteria:

- Is associated with events that have made a significant contribution to the broad patterns of our history (Criterion A).

- Is associated with the lives of persons significant in our past (Criterion B).

- Embodies the distinctive characteristics of a type, period or method of construction, or represents the work of a master, or possess high artistic 
values, or represents a significant and distinguishable entity whose components may lack individual distinction (Criterion C).

- Has yielded, or may be likely to yield, information important to history or prehistory (Criterion D).

(National Register Bulletin \#15, 2002, retrieved from http://www.cr.nps.gov/nr/publications/bulletins/nrb15/nrb15_2.htm)

The second level of historic significance can be found at the state level.

California's criteria are also listed on the OHP website and must meet at least of the following criteria:

- Associated with events that have made a significant contribution to the broad patterns of local or regional history or the cultural heritage of California or the United States (Criterion 1).

- Associated with the lives of persons important to local, California or national history (Criterion 2).

- Embodies the distinctive characteristics of a type, period, region or method of construction or represents the work of a master or possess high artistic values (Criterion 3).

- Has yielded, or has the potential to yield, information important to the prehistory or history of the local area, California or the nation (Criterion 4).

(California Register- Criteria for Designation, 2013, retrieved from http://ohp.parks.ca.gov/?page_id=21238)

The final level of significance to consider is the local level. Since this project is specific to Arroyo Grande, the criteria is listed within the Arroyo Grande Municipal Code. Code section 16.16.135B stipulates that in order for a resource to be designated it must meet at least one of the following:

- It is the site of a significant local, county, state or national historic event.

- It is strongly identified with a person who, or an organization, which significantly contributed to the culture, history or development of the community of Arroyo Grande, the county of San Luis Obispo, the state of California or the United States.

- It is a particularly good example of a period of history or architectural style and a structure of significant character, interest or value as part of the 
development, heritage or cultural characteristics of the city, county, state or nation.

- It is one of the best or few remaining examples in the area possessing distinguishable characteristics of an architectural type or specimen.

- It is a notable work of an architect or master builder whose individual works have significantly influenced the development of the city, county, state or nation.

- It embodies elements of architectural design, detail, materials or craftsmanship that represent a significant architectural innovation.

- It has a unique location or singular physical characteristic representing an established and familiar visual feature of a district, community, county, state or nation.

- The structure or location is located in a geographically definable area possessing a concentration of historic resources that visually contribute to each other and are unified aesthetically.

(City of Arroyo Grande Municipal Code, 16.16.135B, 2014, retrieved from https://library.municode.com/index.aspx?clientld=16194)

It is important to note that just because a structure is listed on either the national or state level that it is not automatically listed on Arroyo Grande's list of designated resources. A resource would certainly be eligible but it must go through the local designation process first to be formally listed.

\section{Implications For Arroyo Grande}

Based on the local context of Arroyo Grande, it can be ascertained that the City address the following:

- Historic building stock: Although the City possesses historic structures, most of them are not designated.

- Lack of designation: Structures are in danger of demolition/inappropriate alterations. Protecting these resources requires a creative approach and is one of the questions asked of fellow preservation planners. 


\section{CHAPTER 4: PAST AND CURRENT PRESEVATION EFFORTS}

The City officially began showing interest in historic preservation as early as 1985. This is when the first historic preservation document was adopted by the City. Since then, the number of preservation approaches and efforts has multiplied. Below is a list of the past and current preservation efforts the City has undertaken.

- 1985: first version of Design Guidelines for Arroyo Grande Village drafted

- 1985: March, informal "Historical Buildings and Sites Survey" conducted by the South County Historical Society

- 1991: informal historic resources survey

- 1994: City Council formally adopted the Design Guidelines and Standards for the Historic Overlay District (D-2.4)

- 2003: Guidelines update adopted by City Council

- 2005: City Council approves the creation of a Historic Resources Committee

- 2005: City Council establishes a historic resources designation process

- 2006: Appointment of first Historic Resources Committee

- 2007: historic designation ordinance adopted

- 2008: Guidelines update adopted by City Council

- 2009: Guidelines update adopted by City Council

- 2011: Formal historic resources survey conducted by historic resources consultant

- 2012: City Council adopts Historic Context Statement 
- 2013: City Council adopts Mills Act property tax abatement program

\section{Design Guidelines And Standards For The Historic Overlay District}

This document has undergone five revisions since its inception in 1985. The document was formally adopted by the City Council in 1994 with the purpose of providing standards and guidelines for development in the Historic Overlay

District (the Village). The document details the following six objectives:

- Safeguard the heritage of Arroyo Grande.

- Encourage public knowledge, understanding and appreciation of the City's past.

- Enhance the visual character of the City and the Village by preserving and promoting diverse and harmonious architectural styles and designs that reflect historic character and stages in the development of the City.

- Conserve valuable material and energy resources by continued use of the existing built environment.

- Protect property values and increase financial and economic benefits to the owners, businesses and residents of Arroyo Grande.

- Ensure that new construction and renovation of existing buildings are compatible with the historic character of the Village area and surrounding neighborhoods.

(Design Guidelines and Standards for the Historic Character Overlay District, 2009, p. 6)

It is important to note that there is a distinction between guidelines and standards. The document defines guidelines as: statements that indicate preference or principles indicated by descriptive statements including "should", "is encouraged", "is desired" and "may". Standards are more stringent and are defined as: statements indicated by language that is unequivocal and that 
prescribe minimum acceptable limits. Statements such as "shall", "is required" and "must" are standards.

According to staff, the current version of the Design Guidelines is widely utilized and extremely effective. Projects that fall under this document's purview are subject to design review by the Historic Resources Committee, the Architectural Review Committee or both. The committees take their work seriously and are committed to the objectives set forth in the document.

\section{Historic Resources Surveys}

Of the surveys on hand, the City relies most heavily on the one conducted by historic preservation consultants Page \& Turnbull. This is because the survey was completed by qualified professionals. What has resulted from the surveys is data that can be used to designate resources. To date, the City has eleven locally designated resources, one of which is state registered and one of which is nationally registered.

City staff is looking to have another survey conducted but is constrained by a lack of funding. The City is hoping for a broader survey that will include more properties as the formal survey only included 25 properties. Additionally, the City would like to look outside the immediate Village area and consider the City as a whole. Surveys play a vital role in the preservation of resources as identification is one of the first steps towards preservation.

\section{Historic Resources Committee}

The formation of the Historic Resources Committee (HRC) came to fruition in order to assist staff, the Architectural Review Committee, Planning Commission 
and the City Council with future determinations regarding the designation and treatment of historic resources. Additionally, the HRC serves as an educational resource providing technical assistance and general information on the process and benefits of historic preservation to area residents and property owners. Staff is pleased with the formation of a Historic Resources Committee. They believe the committee is an integral part in the preservation of resources as the committee was formed with the specific intent of preserving and protecting cultural and architectural resources of Arroyo Grande. Since its inception, the committee has met regularly to vote on projects and to also discuss the future of historic preservation in Arroyo Grande.

\section{Historic Designation Ordinance}

One of the first tasks of the newly formed HRC was the creation of a historic designation ordinance. Staff worked closely with the committee along with an outside consultant in the drafting of an ordinance. The purpose of the ordinance "is to promote the general welfare by providing for the identification, protection, enhancement, perpetuation and use of improvements, buildings, structures, signs, features, sites, places and areas within the city that reflect special elements of the city's historical, architectural, archaeological, cultural or aesthetic heritage for the following reasons:

1. To encourage public knowledge, understanding, appreciation, and use of the city's past;

2. To foster civic pride in the beauty and character of the city and in the accomplishments of its past;

3. To enhance the visual character of the city by encouraging new design and construction that complements the city's historical buildings;

4. To increase the economic benefits of historic preservation to the city and its inhabitants; 
5. To protect property values within the city;

6. To identify as early as possible and resolve conflicts between the preservation of historic resources/districts and alternative land uses;

7. To conserve valuable material and energy resources by ongoing use and maintenance of the existing built environment.

(City of Arroyo Grande Municipal Code, 16.16.135B, 2014, retrieved from https://library.municode.com/index.aspx?clientld=16194)

While both staff and the committee are pleased to have a designation ordinance, they would like to see the designation criteria more in line with state and federal criteria. Additionally, staff would like to see the ordinance strengthened by making doing the wrong thing unattractive by imposing fees and penalties.

\section{Historic Context Statement}

The context statement is a way for potential properties to be evaluated for historic significance. The context statement serves as the framework for the documentation and evaluation of historical resources. Properties are a part of the historic context of a city. Contexts describe the significant broad patterns of development in an area that may be represented by historic properties.

The addition of the context statement to Arroyo Grande's toolkit indicates that the City is committed to preservation. Staff is pleased to have a completed context statement in their toolkit. It not only provides a better and more thorough understanding of the City's history but it provides a complete understanding of how a property fits within the history of the City's development.

\section{Mills Act Property Tax Abatement Program}

The Mills Act is a state law allowing cities to enter into contracts with the owners of historic structures. Such contracts require a reduction of property taxes in 
exchange for the continued preservation of the property. A property must first be designated in order to be considered for a contact.

The Mills Act is the latest preservation tool in Arroyo Grande's toolkit and has yet to be utilized by any residents. Despite its underutilization, City staff is confident that the contracts will prove to be quite attractive in incentivizing preservation. In fact, staff is working with the property owner of an extremely significant resource and hopes to have the contract finalized within the coming months.

\section{Implications For Arroyo Grande}

- Design guidelines: The City could create a new set of design guidelines based off of the Secretary of the Interior's standards and guidelines for the treatment for historic structures. This would serve to inform the public on the appropriate methods for preserving structures composed of various types of materials.

- Surveys: Currently, Arroyo Grande has only had one professional survey of historic structures conducted. If they would like to locally designate more structures as historic, conducting a survey is the first step in the process.

- Historic Resources Committee: The Committee should work to become more educated on the issues surrounding historic preservation. Staff and the Committee can work together to create a list of educational goals the Committee would like to reach.

- Ordinance: Staff should work with the Committee in strengthening the existing ordinance to be more in line with the state standards. 
- Mills Act: This program is a great way to incentivize preservation. Staff and the Committee should work together to devise a way to increase participation. 


\section{CHAPTER 5: METHODS}

For the purposes of ascertaining the most effective preservation approaches for Arroyo Grande, various methods were used to gain a wide understanding on the topic of historic preservation, how cities conduct preservation planning and the history of Arroyo Grande and their preservation approaches. Methods utilized include: case analysis, interviews, local document review and best practices information gathered from scholarly and government sources.

\section{Case Analysis Method}

This method is particularly useful as it provides relevant information on the topic of preservation approaches. This analysis was conducted by creating criteria in which to judge the cases by. This criterion was found while conducting the literature review on best practice methods. According to Preparing a Historic Preservation Plan there are several elements to a good preservation plan. The elements include: statement of goals, definition of historic character, summary of past preservation efforts, historic resource surveys, legal basis for historic preservation, coordinating preservation with land use, incentives for historic preservation, the relationship between preservation and education and an agenda for future action.

For the case analysis, I researched preservation plans (cases) all around the county and started with a pool of five cities: Anaheim, Eureka, lowa City, San Antonio and Burbank. I then reviewed the cases against the criteria set forth by the preservation experts. The following is the chart that was used to determine which of the cases met the criteria: 


\begin{tabular}{|c|c|c|c|c|c|c|c|c|c|}
\hline $\begin{array}{c}\text { Case Analysis } \\
\text { Criteria }\end{array}$ & $\begin{array}{c}\text { Statement of } \\
\text { Goals }\end{array}$ & $\begin{array}{l}\text { Definition } \\
\text { of Historic } \\
\text { Character }\end{array}$ & $\begin{array}{l}\text { Summary of } \\
\text { Past } \\
\text { Preservation } \\
\text { Efforts: } \\
\text { Preservation } \\
\text { Context } \\
\end{array}$ & $\begin{array}{l}\text { Surveys } \\
\text { conducted } \\
\text { according to } \\
\text { best practice } \\
\text { methods }\end{array}$ & $\begin{array}{l}\text { Legal Basis } \\
\quad \text { for } \\
\text { Preservation }\end{array}$ & $\begin{array}{l}\text { Coordinating } \\
\text { Preservation } \\
\text { with Zoning, } \\
\text { Land Use and } \\
\text { Growth } \\
\text { Management }\end{array}$ & \begin{tabular}{|c|} 
Incentives \\
for Historic \\
Preservation
\end{tabular} & \begin{tabular}{|c|} 
The \\
Relationship \\
Between \\
Preservation \\
and \\
Education \\
\end{tabular} & $\begin{array}{c}\text { Agenda } \\
\text { for Future } \\
\text { Action }\end{array}$ \\
\hline \multicolumn{10}{|l|}{ City of Eureka } \\
\hline \multicolumn{10}{|l|}{ Iowa City } \\
\hline \multicolumn{10}{|l|}{$\begin{array}{c}\text { City of San } \\
\text { Antonio }\end{array}$} \\
\hline \multicolumn{10}{|l|}{ City of Burbank } \\
\hline City of Anaheim & & & & & & & & & \\
\hline
\end{tabular}

Table 1 Case Analysis Criteria

In terms of meeting the case analysis criteria, San Antonio received the highest score and lowa City, Burbank and Anaheim all tied for second, with Eureka coming in third. The scores can be somewhat misleading in that they simply provide a numerical score and do not provide a discussion regarding how effective each of the criterion components are. For the purposes of this background report, I chose two of the five cities to help inform the preservation approaches for Arroyo Grande. The discussion of the two choices below illustrates how each of the plans effectively meets the criteria and why they were chosen for further investigation.

\section{Case Analysis: City Of San Antonio Strategic Historic Preservation Plan}

The San Antonio plan is perhaps the most comprehensive document and covers a wide range of preservation topics. The document is divided in five main chapters: 1) Introduction 2) Historic Context 3) State of the City 4) Historic Preservation Plan and 5) Implementation Matrix.

One important chapter within the document is the State of the City. It is within this chapter that the current and past approaches are discussed. This is one of the most important elements in a good preservation plan in that "it alerts government 
leaders to the precedents that should guide good preservation planning and decision making. Second, it may be considered by judges and juries in preservation disputes that end up in courts" (White and Roddewig, 1994, p. 7). This chapter has multiple sections each of which provide great detail regarding the state of the current preservation approaches. Each of the approaches is detailed and provides an analysis of the successes and challenges faced.

Another important chapter is the Historic Preservation Plan. It is in this chapter that the various strategies for preservation are addressed. The chapter is divided into six categories (City Planning, City Zoning, Economic Development, Historic Resources, Incentives and Education and Advocacy). This chapter is designed to bring together many "diverse initiatives, programs, needs, opportunities, goals and principles related to the preservation of San Antonio" (San Antonio Strategic Plan, 2009, p. 5.78). This chapter is the driving force behind the document as it states the needs, goals and objectives related to historic preservation in San Antonio. How these goals actually come to fruition is discussed in the last chapter, Implementation Matrix.

Of all the plan documents reviewed, the San Antonio plan was chosen for further investigation because it provides the most detailed implementation plan. The Implementation chapter is laid out in a matrix format and divides all the information into the six sections discussed in the Historic Preservation Plan chapter. Each of the six strategies has specific recommendations, action steps and potential participants to attain said recommendations. Overall there are close 
to 90 recommendations ranging from micro to macro. According to experts, the implementation chapter is important for three reasons.

One, the agenda will provide times frames and an action plan for implementation of the goals and strategies included in the plan. Two, the agenda will help to set priorities for implementation of the plan. Three, an agenda allows periodic review by local government and the preservation commission to determine the progress in meeting stated goals whether the goals and strategies should be redefined, or whether priorities should be reestablished (White and Roddewig, 1994, p. 19).

While the San Antonio document is lacking a time frame, it does create priorities and allows for review.

\section{Case Analysis: City Of Anaheim Preservation Plan}

The Anaheim Preservation Plan is composed of five chapters as follows: Introduction, Citywide Historic Context Statement, Preservation Policies and Procedures, Design Guidelines for Historic Properties and Resources. This plan was chosen because it is set up in a very logical and easy to follow manner. Of all the plan document looked at it was the easiest to follow and understand. The definition of historic character is clearly stated as are previous preservation efforts. Additionally, the chapter on preservation policies and procedures is organized and clear. It is in this section that the coordination between land use, zoning and historic preservation is discussed.

The chapter on historic character is important because it helps to describe the unique character of Anaheim. The plan clearly lays this out and shows Anaheim's history, emphasizing significant dates, trends, events, eras, people, buildings, architectural styles and neighborhood. The plan goes so far as to plot the significant structures on a map. What is shown is a dense clustering of resources 
in neighborhoods. The plan goes on to discuss the various historic districts within the city and paints a complete picture of the history of development. This chapter more than meets the minimum requirements discussed by White and Roddewig which call for "a complete description of the history of development of the community or neighborhood" (1994, p. 6).

One section of this plan that is unique is the section on design guidelines. Of the five plan documents, Anaheim was the only plan to include design guidelines. It was because of this chapter that this plan was chosen for further investigation. As discussed in previous chapters, design guidelines are an integral part to a preservation plan and this plan provides a great overview of the Secretary of the Interior's standards and guidelines for the treatment of historic structures. Some guideline topics include roofs, porches, colors, windows and new construction. This information is extremely practical in that it provides images of dos and don'ts. Additionally, it features pictures of what structures look like with inappropriate alternations and what they look like once the design guidelines are implemented. This is helpful because the pictures speak for themselves and more importantly, it shows how great the historic houses look once they are treated according to the standards. These pictures help to make the case for the importance of design guidelines in the preservation of historic resources.

\section{Interviews With Preservation Planners}

The case analysis provided the framework and knowledge for me to conduct interviews with preservation planners in three key cities; Anaheim, Burbank and Eureka. I chose to interview planners at these cities because each city 
possesses preservation plans that contain the elements set forth by the best practices and literature. The planner interviews helped to inform the interview and discussion questions I poised at the Historic Resources Committee. All of the information gathered was used to inform the preservation plan approaches document for Arroyo Grande (Appendix 1) and is laid out in Chapter 6.

The interview questions naturally evolved out of the case analysis and centered on the following themes:

- Plan successes and challenges

- Motivation of community members

- Preservation ordinances

- Education programs

From these themes I developed a set of specific questions. I did my best to stick to the questions but allowed the interviewees to freely discuss their city's preservation plan. I wanted the interview to flow naturally and feel like a conversation. This allowed the interviewees to address questions I had not considered and provided for an enriching and productive discussion.

The following interview questions were asked of the preservation planners from Anaheim, Burbank and Eureka:

- What is your role or involvement in the preservation process?

- What do you think about the preservation plan document? How do you feel about the different components? 
- What part of the plan do you feel is effective? Why?

- What part of the plan do you feel is ineffective? Why?

- As preservation progresses in you city, do you feel any part of the plan should be updated or changed?

- What do you find to be the most effective in terms of motivating community members to participate in historic preservation?

- Do you currently have a preservation ordinance in your city's municipal code? If so, do you feel it adequately protects resources?

- Have you been able to spread the word on your historic preservation program? If so, what do you think of the method?

- How have groups in town (residents, property owners, business owners) demonstrated an interest in historic preservation? How did this interest arise?

- What do you consider the most successful aspects of the plan? What would you improve?

- What was the most challenging component of the plan to implement?

- If you could go back to when the plan was adopted and implemented, would you have done anything differently? What would you absolutely not change?

- What kind of review/advisory bodies look at historic projects when they come in?

- Currently, the City of Arroyo Grande has a list of locally designated structures. We also have a lot of structures that are not locally designated 
but that are of historic interest that are at risk of being demolished or inappropriately altered. Do you have a similar problem or how would you propose discouraging these types of things from happening?

- If there anything else that I did not ask that you think I should know about your preservation program?

\section{Interviews With Historic Resources Committee}

For a local perspective, I interviewed members of the Historic Resources Committee (HRC) who are also Arroyo Grande residents. I prepared a questionnaire, list of discussion questions and brief memo describing the project. All materials were sent out in the regular agenda packets for Committee review prior to the meeting.

Two meetings were held with the Historic Resources Committee. The first meeting was held on April 4, 2014 and the second on May 16, 2014. Discussion questions centered on the following themes:

- Regulation vs. incentives

- Education

- Preservation goals

Most of the questions were open ended in order to facilitate a discussion. Specific questions included:

- What do you like about the current preservation approach Arroyo Grande is utilizing? 
- What would you change about the current preservation approach?

- What are some of the challenges in the current approach and how should we go about addressing these challenges?

- What do you think of our current designation ordinance?

- What should we do to educate the public on historic preservation?

Both the interviews with the Committee and the planners from the three key cities helped to inform how Arroyo Grande should proceed with their preservation approach. Implications for Arroyo Grande are discussed in the following section. Additionally, Appendix One provides a more detailed discussion on specific issues, goals and actions for how the City can move forward with their preservation approach.

\section{Local Document Review}

In order to learn about the history of Arroyo Grande and their preservation approaches a review of local documents was conducted. Documents included:

- Arroyo Grande Municipal Code

- Arroyo Grande Historic Context Statement

- Arroyo Grande's Village Design Guidelines

- Minutes and agendas from previous meetings (City Council, Planning Commission, Architectural Review Committee and Historic Resources Committee)

These sources yielded a wealth of information on the local context of Arroyo Grande and were used to not only inform this project but were also used in the 
formulation of the Preservation Approaches document (Appendix 1). More specific information on the local documents reviewed can be found in Chapter 4 .

\section{Best Practices}

In order to have an understanding on the topic of historic preservation, a literature review was conducted. This included research, reading and making conclusions on both scholarly articles and government/trade publications. Best practices included the research of three key topics in preservation: historic resource surveys, historic preservation ordinances and guidelines for the treatment of historic structures. Some of the most fruitful information came from government sources. This included the federal government (National Park Service and the Secretary of the Interior) and the state (Office of Historic Preservation). All of the information gathered served to inform this project and the Preservation Approaches document (Appendix 1). More specific information on best practices can be found in Chapter 2 . 


\section{CHAPTER 6: FINDINGS FOR ARROYO GRANDE'S PRESERVATION}

\section{APPROACH}

While Arroyo Grande's current preservation approach does possess a significant number of preservation programs and tactics, there is room for improvement. In order for the City to better promote historic preservation and protect resources, they should have a complete preservation program. As previously discussed, a complete preservation program consists of seven different components: 1) historic resource surveys, 2) historic preservation ordinance, 3) design guidelines, 4) incentives, 5) education programs, 6) preservation plan, and 7) recognition/awards. Currently the City has only four out of the seven (surveys, ordinance, design guidelines and incentives). This chapter begins with the interview results from both the planner interviews and interviews with the Historic Resources Committee and clearly lays out the implications for Arroyo Grande. It goes on to lay out issues within the City's current preservation approach, which based on the research presented in previous chapters of this project, should be addressed. The findings discussed below directly informed the recommended goals and actions for Arroyo Grande and are discussed in Appendix 1. The chapter concludes with a discussion of the missing preservation components.

\section{Methods Findings: Interview Results}

\section{Anaheim interview results}

Christine Nguyen, associate planner, is in charge of Anaheim's Preservation Program. She works mostly with Mills Act properties and also answers questions pertaining to design review. When asked about the current preservation plan, Ms. 
Nguyen stated that the plan functions well. It acts as a form of guidance and provides property owners information on architectural styles and the Standards set forth by the Secretary of the Interior. Ms. Nguyen stated the plan is not really a policy document but provides a framework and recommendations.

When asked about the most effective component of the plan, Ms. Nguyen stated the Mills Act program is successful, which is supported by its high participant rate (286 contracts, third largest program in the state). One reason the program is successful is because the City provides plaques to structures that are under the Mills Act. This recognition gives property owners a sense of pride. Not only do Mills Act properties brighten the lot they are located on, but the brightening has a ripple effect as neighboring properties become better maintained and cared for. The current preservation approach does not provide protection to structures that are not under the Mills Act. This is because Anaheim's preservation program is based solely on the Mills Act. Staff would like to see protection for structures not designated under the Mills Act. Ms. Nguyen explained that when the Redevelopment Agency was intact, they provided money to re-site structures that were in danger of demolition. Without the funds from the now dissolved Redevelopment Agency, the City cannot afford to relocate structures. Potentially historic structures that are in danger of demolition must undergo a 60 day noticing period. However, this period is not effective and does not allow adequate time for resources to be gathered to re-site the structure.

Ms. Nguyen explained how Anaheim's program is set up. The historic districts were formed by citizen involvement who rallied together to create the Historic 
Preservation Committee. Ms. Nguyen stated that all structures within historic districts are subject to review when alterations or demolitions are proposed. The Committee worked with City Council to establish a letter of understanding. It was this letter of understanding that created the historic districts. Any structure within a historic district is eligible for a Mills Act contract. Structures outside the historic districts can be eligible for the Mills Act but must first be professionally surveyed and have the survey findings decided on by the Historic Preservation Committee. Interest in historic preservation grew out of community interest. It was the citizens and property owners that came together to create the driving force behind the City's current movement. Ms. Nguyen explained that the City really did not have to do any outreach to garner support as the community was rallied and ready to go.

\section{Burbank interview results}

Martin Potter, assistant planner, is in charge of Burbank's historic preservation program. His role in the process is taking in historic designations, Mills Act program and working with the City's Heritage Commission. When asked about the effectiveness of the plan, Mr. Potter stated when the preservation ordinance was updated in 2009 and the Mills Act program was added, this created an interest in preservation. However, he feels it is the newly adopted Mills Act that could use updating. This is because City Council can be very discerning when it comes to approving contacts. Mr. Potter stated he would like to see the process in which applicants submit their applications and work programs for Mills Act become stronger so City Council is more likely to approve. The Mills Act is also, 
in Mr. Potter's opinion, a great way to motivate the community in participating in historic preservation.

When asked if Burbank had a preservation ordinance, Mr. Potter stated the City did. It is under the ordinance that historic designations are made. Additionally, the ordinance gives the Heritage Commission the authority to review projects and approve or deny alterations made to historic structures.

In terms of spreading the word on historic preservation, Mr. Potter cited several successful tactics Burbank has utilized. May is historic preservation month and planning events during this month can garner support. Other options include, hosting events at the local farmers market, creating posters to hang in City Hall and the library, creating a Facebook page, adding information about historic preservation to the City's website and the City's public access channel. Mr. Potter stated that some of these tactics have worked for Burbank, but it really depends on the dynamic of property owners and residents. Mr. Potter stated that preservation in Burbank is mostly resident driven. A local group was formed by residents interested in preservation who pushed for polices to be drafted by the City. Mr. Potter stated the importance of staff taking the initiative to get outreach and education programs started.

\section{Eureka interview results}

Kristen Goetz is the senior planner for the City of Eureka. Among her many job duties she is tasked with assisting applicants in the preservation process and acting as the secretary to the Historic Preservation Commission. The City took 
their preservation program one step further by adopting the preservation plan as an element in their general plan. Additionally, the City is also a Certified Local Government (CLG) which allows them to apply for grants to further and strengthen their existing preservation approach.

Getting the community motivated to participate in historic preservation has not really been a task for Eureka. The community and property owners have been involved and committed to historic preservation before the City enacted preservation policies. This involvement stemmed from a general interest in historic preservation from the Humboldt County Historical Society. The City's preservation ordinance followed the community's interest and is the basis for preservation. Property owners are allowed to opt out if they choose. Currently, the City has around 400 properties on their local register.

Currently Eureka participates in the Mills Act program. To date, only one property has come forth for designation. The City is interested in having more properties apply and feel it is a great way to incentivize preservation.

Ms. Goetz cited the CLG status of the City as a major reason for the City being able to accomplish so many preservation tasks. One accomplishment made possible by a CLG grant was the creation of an interactive preservation website.

\section{Historic Resources Committee interview results}

The Committee provided a wealth of information on the local context and implications for Arroyo Grande. Below are the findings from the discussion at the meetings: 
- The City needs a public outreach and education program.

- The current designation ordinance should be updated to match the standards set forth by the state.

- More historic surveys should be conducted.

- The Mills Act Program needs to be better known by property owners.

- Arroyo Grande should become a Certified Local Government.

- Recognize structures for their commitment to preservation.

\section{Implications For Arroyo Grande}

- Establishing historic districts is one way to help protect properties that have not been individually designated from demolition and inappropriate alterations.

- An education program is key to getting the community on board with historic preservation.

- Certified Local Government (CLG) status could help Arroyo Grande with funding preservation work.

- A recognition program helps to spread the preservation word and also helps create neighborhood pride.

- The Mills Act is a great way to incentive preservation. Therefore the program should be widely publicized. 


\section{Best Practices And Literature Review Findings}

\section{Historic resource surveys}

Currently the City has only had one professional survey conducted. This limited survey consisted of 25 properties within the Village area of the City. A few other surveys have been conducted but not by professionals. Surveys are important for preservation in Arroyo Grande as they serve as a starting point in which potential historic resources are identified and protected. Should Arroyo Grande want to preserve their historic building stock, they need to conduct surveys on a regular basis. Conducting surveys ensures under the law that no building is singled out. As discussed in Chapter 2, this is important from a legal standpoint as it "guards against singling out some owners of historic structures for designation while other owners with properties as equally as meritorious under criteria adopted by a community for designation of landmarks or historic districts escape consideration" (White and Roddewig, 1994, p. 7) While it would be ideal for Arroyo Grande to hire a qualified professional to conduct the surveys, under the current designation process, the Historical Resources Committee is qualified to make decisions regarding the merit of structures.

Should the City decide to undertake the survey process, they would benefit from the systematic approach. The National Park Service describes this approach as "scheduling consideration by reference to discrete geographic area or political districts of the city (e.g., north side first, then the south side, etc.) that will be considered" (White and Roddewig, 1994, p. 7). This could be beneficial as there are potential historic resources all throughout the city. It is not unheard of for 
cities to undertake city-wide surveys in hopes of compiling information on all historic resources. While it must be recognized that this is a huge endeavor, it is not impossible and could be done in phases. Once the surveys are conducted, the committee could review the results and begin the designation process of the appropriate buildings.

\section{Historic preservation ordinance}

The City adopted their current preservation ordinance in 2007. The ordinance is the basis for designation and protection of historic resources. Without an ordinance, historic structures could be demolished or inappropriately altered. Currently, Arroyo Grande's ordinance has all the basic parts of an ordinance as described by the Office of Historic Preservation but lacks the detailed and descriptive language to best protect historic resources. As previously discussed in Chapter 2, the implications of the current state of the ordinance indicate that should the City want to strengthen their preservation approach, they should update their ordinance to be more in line with what the Office of Historic Preservation recommends for preservation ordinances.

The current ordinance contains the following sections:

- Purpose and intent

- Authority- designation criteria

- Applicability

- Designation process

- Development and building permits

- Additional findings for the alteration or demolition of a designated resource 
- Historic resource protection tax incentives

A review of Arroyo Grande's ordinance against the requirements set forth in Drafting Effective Historic Preservation Ordinances by the Office of Historic Preservation reveals that Arroyo Grande is lacking in a few sections of their ordinance.

Within the authority section, there should be language that requires some the committee members to be qualified. The utilization of qualified members such as those trained in historic preservation, architecture, landscape architecture and historians provides more clout to the committee and their decision making power. It is recognized that Arroyo Grande is a smaller city that may have limited access to qualified professionals. If the city is not able to retain such qualified individuals, language should be provided in the ordinance that discusses the training of lay committee members.

The authority section should also explicitly state the scope of powers of committee members. The Office of Historic Preservation recommends the following:

- Survey and identification of historically and architecturally significant structures and areas;

- Establishment of standards and procedures for designation of historical resources;

- Designation of historical resources; 
- Review of applications for alterations, construction, or demolition of historical resources and all structures within historic districts;

- Coordination and supervision of educational activities;

- Purchase or sale of property;

- Acceptance of easements and other less-than-fee simple donations of property;

- Enforcement of ongoing maintenance requirements for historical resource;

- Acceptance of preservation funds for various sources, and

- Review of zoning amendments and comprehensive plans relating to historic preservation.

(OHP Technical Assistance Bulletin \#14, 2005, p. 82)

Within the designation process section, the City should include language regarding appropriate review standards. The current ordinance makes no mention of how to review projects. The Office of Historic Preservation recommends using the Secretary of the Interiors Standards and Guidelines to formulate review standards. This review process should result in a Certificate of Appropriateness (COA). A COA is what approves the project. The COA review process is important as it ensures that fair and orderly hearings are conducted. The Office of Historic Preservation provides the following procedural elements:

- The applicability of the review process and criteria (e.g., types of projects, any exemptions);

- The basic process (e.g., initiation, timing); 
- Contents of an application;

- The criteria or source of criteria to be applied; and

- Any specific powers (e.g., conditional permit approval) deemed appropriate for the certification process.

(OHP Technical Assistance Bulletin \#14, 2005, p. 83)

One final section that should be added to the existing ordinance is a section on enforcement. "A preservation ordinance will only be as effective as the power and willingness of the community to enforce it" (OHP Technical Assistance Bulletin \#14, 2005, p. 79). The current Arroyo Grande ordinance is lacking any firm enforcement which potentially means that inappropriate alterations or demolitions could occur if property owners find that prospective profits from redeveloping the site outweigh the penalties in the ordinance. Arroyo Grande could benefit from including language regarding noncompliance in the following topics: fines, injunctive relief and compliance orders, receiverships and entry on to land to correct violation, forcing reconstruction, loss of further entitlement and maintenance and upkeep of historic properties.

\section{Design guidelines}

Currently, Arroyo Grande has design guidelines for one area of the City. The Village is the City's downtown area and appears to possess a high concentration of potentially historic structures. Design guidelines apply to the Village area because there is an overlay district. Overall, the design guidelines seem effective at preserving the character and historic feel of the Village. However, should the 
City wish to designate more buildings, particularly outside of the Village area, design guidelines should be created and implemented. When thinking about design guidelines, a good place to start is with the Secretary of the Interior. Chapter 2 provides a detailed discussion on the guidelines and standards developed by the Secretary of the Interior. While Secretary of the Interior's Standards and Guidelines are somewhat vague, they represent a great starting point for any city looking to author guidelines and standards.

\section{Incentives}

Currently, Arroyo Grande has the Mills Act Property Tax Abatement program in place to offer as an incentive for locally designated structures. This incentive is extremely popular with many municipalities in California. The program is an effective way to incentivize preservation and to coax property owners in the right direction. Implications of the current approaches of this program for Arroyo Grande have only to do with the fact that the program is not widely known by the public. Both the Historic Resources Committee and the preservation planners interviewed emphasized the importance of educating the public on the Mills Act program. This can be achieved through a vigorous public outreach program. Once property owners are aware of the many benefits, participation in the program and historic preservation should increase. 


\section{Components yet to be implemented into Arroyo Grande's preservation program}

\section{Education}

The education component is incredibly important to the overall success of the preservation program. According to the planner interviews, an education program is the driving force behind a successful preservation approach. This is because, without the public's participation and buy-in, preservation is extremely difficult. Since Arroyo Grande does not have an educational outreach program, this means that their preservation approach is limited. Implications for the limited approach include low participation and decreased public interest. Should Arroyo Grande want to increase participation in historic preservation, an educational outreach program should be created. This requires work on both the part of City staff and the Historic Resources Committee. Further specific recommendations are discussed in Appendix 1.

\section{Awards/recognition}

Providing recognition to property owners who preserve their historic properties is a key component in making preservation work. Not only does it create a sense of pride, but it also helps to spread the word on historic preservation. Arroyo Grande does have an award program in place but has not utilized it. Since the City is looking to increase the participation in historic preservation, they should consider utilizing the recognition program. Other cities have similar recognition programs that are successful. One such city is Anaheim. Anaheim provides recognition of those properties that have entered into Mills Act contracts by 
providing property owners a plaque in which they can affix to their historic structures. Anaheim's preservation planner cited benefits of recognition including: better maintenance of property including the yard and increased neighborhood pride. Arroyo Grande could experience similar benefits and should seriously consider utilizing the program.

\section{Preservation plan}

A preservation plan is a necessary component for a complete preservation program and helps bring together all the different parts. As previously discussed in Chapter 2, the preservation plan not only brings all information together but helps to lay out the preservation issues, goals and actions for the future. This document has served to inform the preservation approaches plan document (Appendix 1) that the City can utilize to help administer their preservation program. 


\section{BIBLIOGRAPHY}

No author. Arroyo Grande Municipal Code (2014). Chapter 16.16.135. Retrieved February 26, 2014 from

https://library.municode.com/index.aspx?clientld=16194.

No author (n.d.) California State Parks Office of Historic Preservation. California Register, Criteria for Designation. Retrieved February 20, 2014 from http://ohp.parks.ca.gov/?page_id=21238.

City of San Antonio. (2009). Strategic Historic Preservation Plan San Antonio, Texas. Chicago, IL: Lakota Group.

Cullingworth, B. (1997) Planning in the USA: Policies, issues and processes. New York: Routledge.

No author. Design Guidelines and Standards for the Historic Character Overlay District (D 2.4). (2009). City of Arroyo Grande, California. Retrieved March 26, 2014 from http://www.arroyogrande.org/DocumentCenter/Home/View/280.

Drafting Effective Preservation Ordinances: Office of Historic Preservation. (2005) Retrieved November 9, 2013, from http://www.parks.ca.gov/pages/1054/files/14_hp_ordinances.pdf

Feilden. B.M. (2003). Conservation of Historic Buildings. Oxford: Architectural Press.

Kohtz, D. J. (2012). Improving tax incentives for historic preservation. Texas Law Review, 90(4), 1041-1064.

Ligibel, T.J., Tyler, N. et al. (2009). Historic Preservation: An Introduction to its History, Principles, and Practice. New York: W.W. Norton \& Company, Inc.

Murtagh, W.J. (1997). Keeping Time: The History and Theory of Preservation in America. New York: John Wiley \& Sons.

No author (n.d.) National Trust for Historic Preservation. Heritage Tourism. Retrieved March 20, 2014 from http://www.preservationnation.org/information-center/economics-ofrevitalization/heritage-tourism/. 
National Park Service: National Register Bulletin 15. How to Apply the National Register Criteria for Evaluation. (2002). Retrieved January 16, 2014 from http://www.nps.gov/nr/publications/bulletins/nrb15/INDEX.htm.

National Park Service: Historic Preservation Planning Program. (2013) Retrieved November 9, 2013, from http://www.cr.nps.gov/HPS/pad/planpubs.htm

National Park Service: National register Bulletin 24. Guidelines for Local Surveys. (1985) Retrieved November 13, 2013 from http://www.nps.gov/history/nr/publications/bulletins/nrb24/nrb24.pdf

National Park Service: Historic Context Statements. (n.d.) Retrieved November 15, 2013 from http://www.nps.gov/historiccontexts.pdf

No author (1999) Office of Historic Preservation. National Register of Historic Places Fact Sheet. Retrieved from January 16, 2014 from http://www.ohp.parks.ca.gov/pages/1054/files/nrfacts.pdf.

Page and Turnbull (2013). Historic Context and Survey Report. Retrieved March 21, 2014 from http://www.arroyogrande.org/DocumentCenter/Home/View/1389.

Roddewig, R.J., White, B.J. (1994) Preparing a Historic Preservation Plan. Washington D.C.: American Planning Association.

The Secretary of the Interior's Standards for the Treatment of Historic Properties. (2001) Retrieved November 14, 2013, from http://www.nps.gov/hps/tps/standguide/

Wojno, C. (1991). Historic Preservation and Economic Development. Journal of Planning Literature, 5(3), 296-306.

Woodward, L. (2010). Local Preservation Ordinances: Making them Work in Your Community. The Alliance Review, National Alliance of Preservation Commissions. Nov/Dec 2010 


\section{APPENDIX 1: HISTORIC PRESERVATION PLAN FOR ARROYO GRANDE}
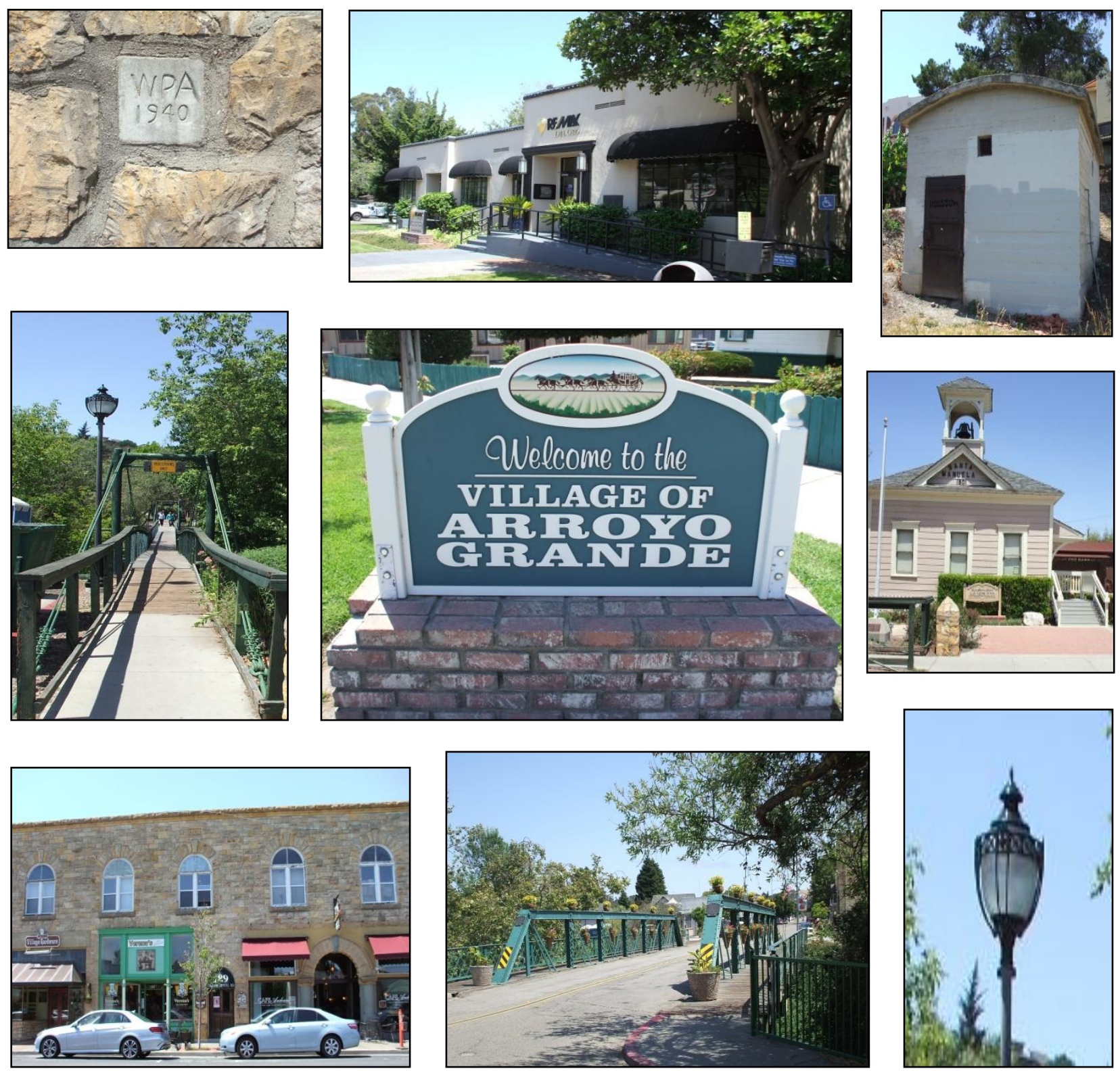


\section{HISTORIC PRESERVATION APPROACHES PLAN FOR ARROYO GRANDE}

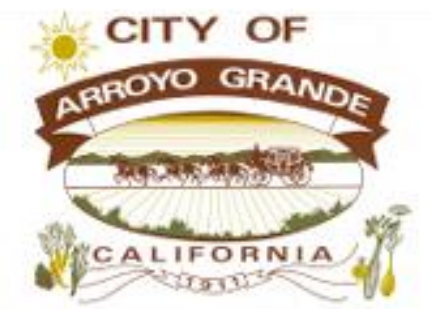

June, 2014

Submitted to:

City of Arroyo Grande

Community Development Department

300 East Branch Street

Arroyo Grande, CA 93420

Submitted by:

Rachel E. Grothe, MCRP

Planning Intern 


\footnotetext{
Table of Contents

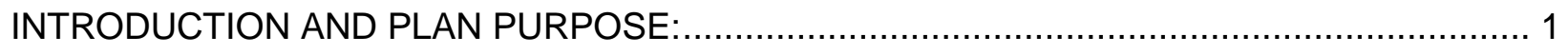

LEGAL FRAMEWORK FOR HISTORIC PRESERVATION: ................................................ 2

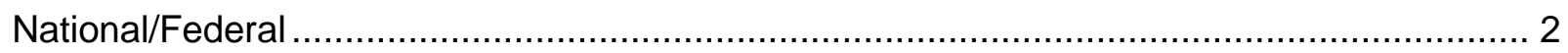

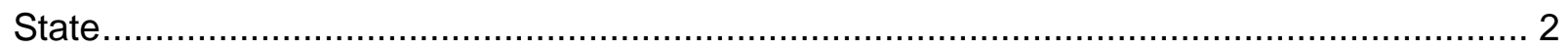

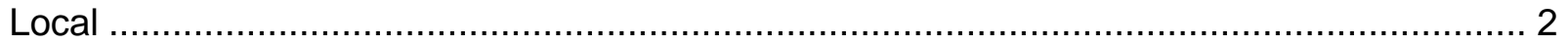

PREPARING THE HISTORIC PRESERVATION APPROACHES DOCUMENT ....................... 4

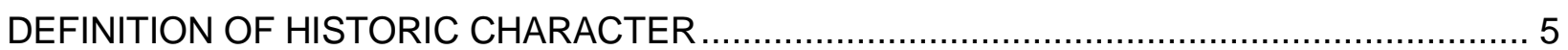

SUMMARY OF CURRENT AND PAST PRESERVATION EFFORTS:

Design Guidelines and Standards for the Historic Overlay District:....................................10

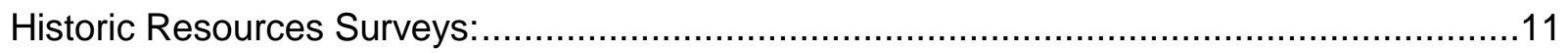

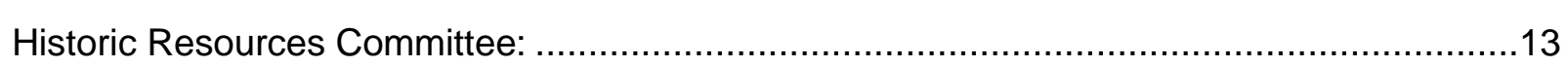

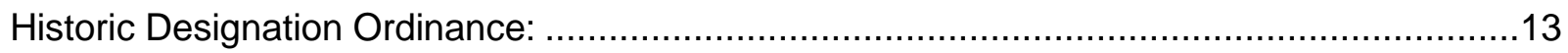

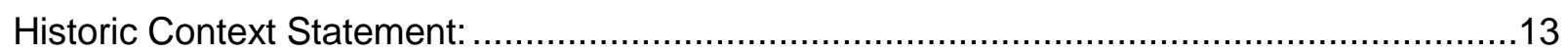

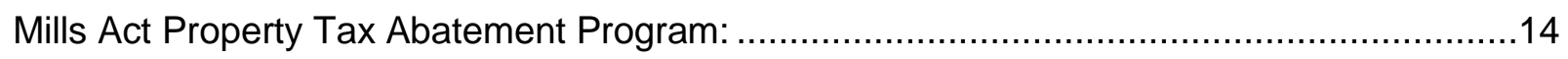

COMPONENTS YET TO BE INCORPORATED INTO ARROYO GRANDE'S PRESERVATION

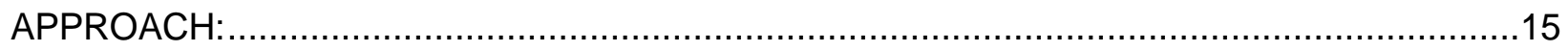

Education Program:

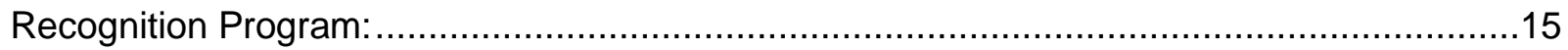

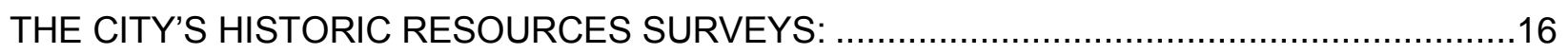

HISTORIC PRESERVATION ISSUES, GOALS AND ACTIONS: ........................................17
} 


\section{INTRODUCTION AND PLAN PURPOSE:}

Historic preservation is a vital key to maintaining a community's character and identity. The mission of Arroyo Grande's historic preservation program is:

- To encourage public knowledge, understanding, appreciation, and use of the past;

- To foster civic pride in the beauty and character of the City and in the accomplishments of its past;

- To enhance the visual character of the City by encouraging new design and construction that complements the city's historical buildings;

- To increase the economic benefits of historic preservation to the City and its inhabitants;

- To protect property values within the City;

- To identify as early as possible and resolve conflicts between the preservation of historic resources/districts and alternative land uses;

- To conserve valuable material and energy resources by ongoing use and maintenance of the existing built environment.

Preservation of historic resources fosters neighborhood pride, provides valuable connections to the past and creates a sense of community and place. Preservation efforts help bolster the local economy through downtown revitalization, economic development and from revenue generated from heritage tourism. Preservation also serves as a tool in comprehensive planning efforts by providing city officials and decision makers direction for decisions in the management of land uses, historic resources, development and design.

Since the humble beginning of preservation work in Arroyo Grande back in 1985, the City has shown increased commitment of historic preservation. This is evidenced by their numerous policies that have been codified over the years. In the same spirit of commitment, Arroyo Grande is seeking to improve and strengthen their existing approach. One way to achieve this is though the creation of a preservation plan. A preservation plan is a compilation of best practice preservation approaches. These varied approaches view preservation from a holistic stance and provide a proactive means of planning for the preservation and protection of a community's character and historic resources. The purpose of this plan document is to strengthen the City's existing preservation program and to help resolve any existing and future conflicts between competing land use goals. Additionally, this plan functions as a proactive means of planning for the future protection of the City's character and heritage. 


\section{LEGAL FRAMEWORK FOR HISTORIC PRESERVATION:}

The legal basis for historic preservation in Arroyo Grande is provided by the National Historic Preservation Act (NHPA), the California Environmental Quality Act (CEQA) and Arroyo Grande Municipal Code 16.16.135. Historic resources within Arroyo Grande may be designated under federal, state and local program requirements.

\section{National/Federal}

The registering and managing of all historic resources on the national level is administered by the National Park Service. The National Park Service maintains a list of all federally recognized districts, sites, buildings, structures and objects that are significant in American history, architecture, archaeology, engineering and culture. Specifically, resources are preserved under Section 106 of the National Historic Preservation Act (NHPA) of 1966. The review process of Section 106 is designed to ensure that historic properties are considered during any federal project planning. Federal projects that fall under Section 106 are those that are listed on the National Register of Historic Places or are eligible under listing.

\section{State}

The California Environmental Quality Act (CEQA) is a state law that requires government agencies to disclose any possible impacts that proposed projects may have on the environment. This includes cultural and historical resources. The most common marker for what is considered historic under CEQA are structures that are over 50 years in age. Additionally, properties that are listed on the California Register of Historic Resources are subject to CEQA review.

\section{Local}

The local basis for historic preservation is section 16.16.135 of the Arroyo Grande Municipal Code. The ordinance outlines the purpose and intent of the City's Preservation Program, the designation authority of the Historic Resources Committee, the criteria and procedures for designation of resources and the treatment of designated resources.

The City's designation process may be initiated by anyone including Committee members, citizens of Arroyo Grande, property owners, the Community Development Director or any of the decision making bodies in the City. Appropriate information must be submitted to the Historic Resources Committee to make a decision and then a recommendation to the Community Development Director on a structures historical significance. The ordinance outlines eight criteria under which a structure may be designated:

- It is the site of a significant local, county, state or national historic event.

- It is strongly identified with a person who, or an organization, which significantly contributed to the culture, history or development of the community of Arroyo Grande, the county of San Luis Obispo, the state of California or the United States.

- It is a particularly good example of a period of history or architectural style and a structure of significant character, interest or value as part of the development, heritage or cultural characteristics of the city, county, state or nation.

- It is one of the best or few remaining examples in the area possessing distinguishable characteristics of an architectural type or specimen. 
- It is a notable work of an architect or master builder whose individual works have significantly influenced the development of the city, county, state or nation.

- It embodies elements of architectural design, detail, materials or craftsmanship that represent a significant architectural innovation.

- It has a unique location or singular physical characteristic representing an established and familiar visual feature of a district, community, county, state or nation.

- The structure or location is located in a geographically definable area possessing a concentration of historic resources that visually contribute to each other and are unified aesthetically.

Once a structure is designated, any work beyond that of routine maintenance may not be made without the issuance of a minor use permit. The minor use permit for work is presented to the Historic Resources Committee who makes a recommendation to the Community Development Director. 


\section{PREPARING THE HISTORIC PRESERVATION APPROACHES DOCUMENT}

To assist in the preparation of this plan document, the City worked with graduate student Rachel Grothe of the City and Regional Planning Department at Cal Poly San Luis Obispo. To begin the process, Rachel conducted extensive background research from a variety of government and scholarly sources on the topic of historic preservation. Additionally, Rachel worked closely with City staff and the Historic Resources Committee to ascertain the context of historic preservation in the City. To gain a broad understanding of preservation in Arroyo Grande, Rachel gathered and reviewed planning publications, city records, historical survey forms and reports and Historic Resource Committee meeting minutes. Another integral part of the research that served to inform this document was interviews with historic preservation planners. Rachel interviewed planners from three cities across California; Anaheim, Eureka and Burbank. The major findings from these interviews are as follows:

- Incentives are key in getting property owners to participate in historic preservation, specifically the Mills Act program.

- Public education is an absolute necessity in getting preservation to work.

- Designating properties as local resources through a local designation ordinance is an effective way to ensure the protection of historic resources.

- Preservation is not successful unless the public is on board. The most effective preservation programs are resident/locally driven.

Public participation and outreach involved the members of the Historical Resources Committee. The Committee is unique in they are both members of the pubic and committee members. The Committee is appointed by the City Council in order to represent the residents of Arroyo Grande in decisions related to historic preservation. An interactive workshop and interview session was facilitated by Rachel Grothe and City staff. This session was designed to provide an opportunity for Committee members to discuss local preservation issues.

Rachel met with the Committee members a second time to present the findings from the research. The Committee members provided valuable feedback on the implications of historic preservation for Arroyo Grande. Specifically, Rachel wanted to ensure that the issues, goals and actions stated in the final section of this document, adequately represented the Committee's vision for preservation in Arroyo Grande. 


\section{DEFINITION OF HISTORIC CHARACTER}

Arroyo Grande lies in the heart of San Luis Obispo County along California's central coast and is tucked about four miles inland from the Pacific Ocean. The 5.8 square mile city is nestled along lush rolling hills and dotted with numerous creeks and is approximately sixteen miles south of San Luis Obispo.

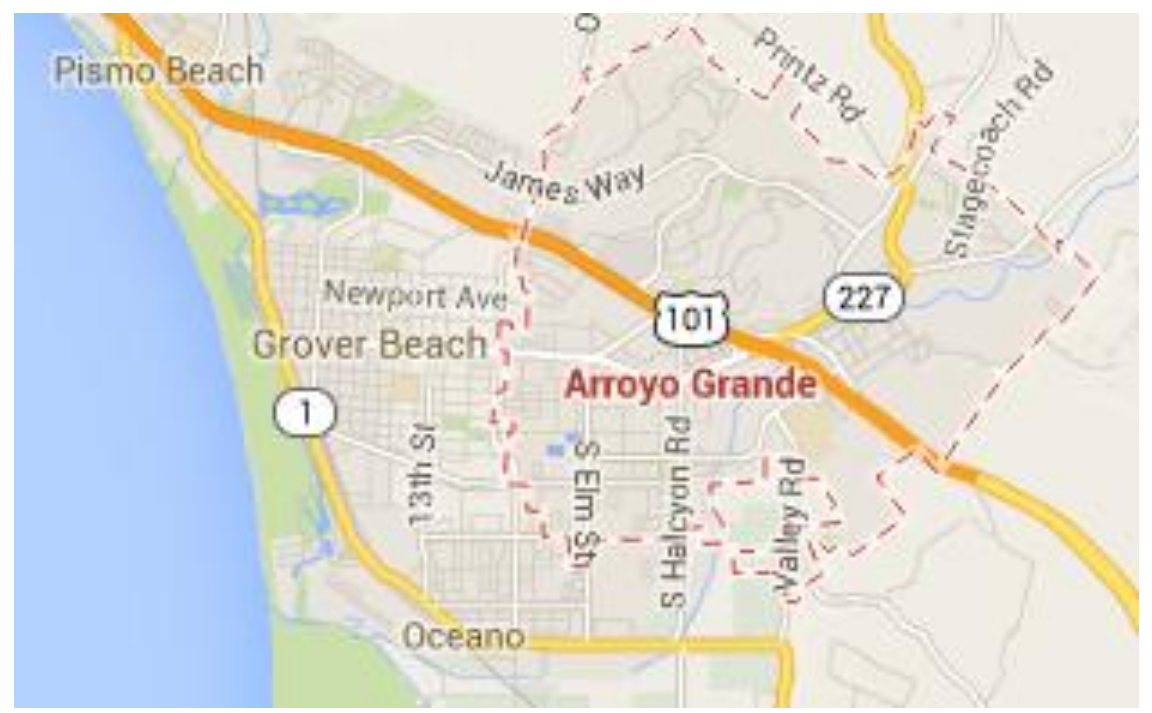

Figure 1 Map of Arroyo Grande

The development of Arroyo Grande can be traced back to the early-1800s with a land grant claimed by Francis Ziba Branch. Prior to this, in the 1700s, the area was occupied by the Chumash Indians. If wasn't until the late 1700s that the Spanish and Mexican periods began. It was during this time that Branch claimed his land grant. During the late 1800s, Branch slowly began selling off pieces of his land. It was this parceling off of land that laid the foundation for Arroyo Grande's growth.

In 1862 Arroyo Grande became a political township. The area flourished and what is now the present day Village became the town. There were a few shops, a church, school and even a hotel and newspaper. The growth of the town can be attributed to the local agricultural industry, which boasted rich and fertile soils. As the town continued to prosper, smaller family farms began sprouting up on subdivided land. With these smaller farms, the residential stock of Arroyo Grande increased and the town began spreading out. This prompted further subdivisions with

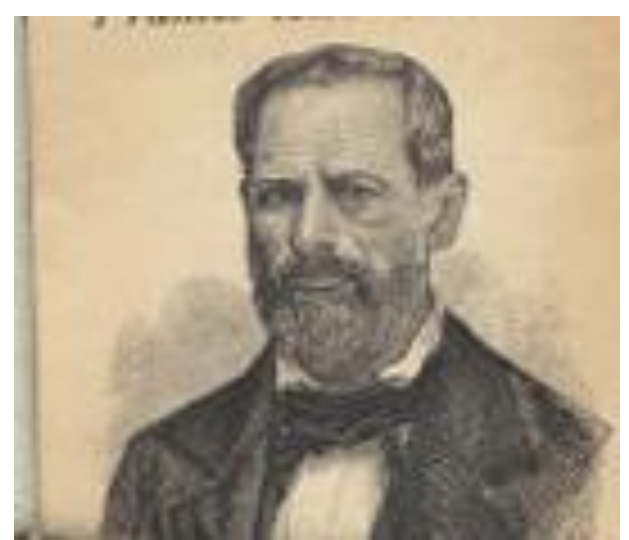

Figure 2 Francis Ziba Branch residential units springing up just south of the Village. All of the growth poised Arroyo Grande for incorporation. On July 10, 1911, Arroyo Grande was officially incorporated as a city in San Luis Obispo County.

The Village area was the original site of Arroyo Grande and naturally developed as the City's commercial core. This development was served by the San Luis Obispo Railroad which allowed 
for Arroyo Grande and the surrounding areas to ship produce and goods to areas as far off as San Francisco. The main street running through the Village, Branch Street, boasted a barber shop, post office, meat market, bank and two grocery stores. These businesses were housed in one-story wood frame buildings with a simple Western false front style. Other notable buildings were constructed of stone and brick. One important building was the Arroyo Grande Bank, constructed out of brick in 1905 this structure still remains on the corner of Branch and Bridge streets. As Branch Street continued to develop, so did the streets surrounding it including Bridge, Nevada and Mason Streets.

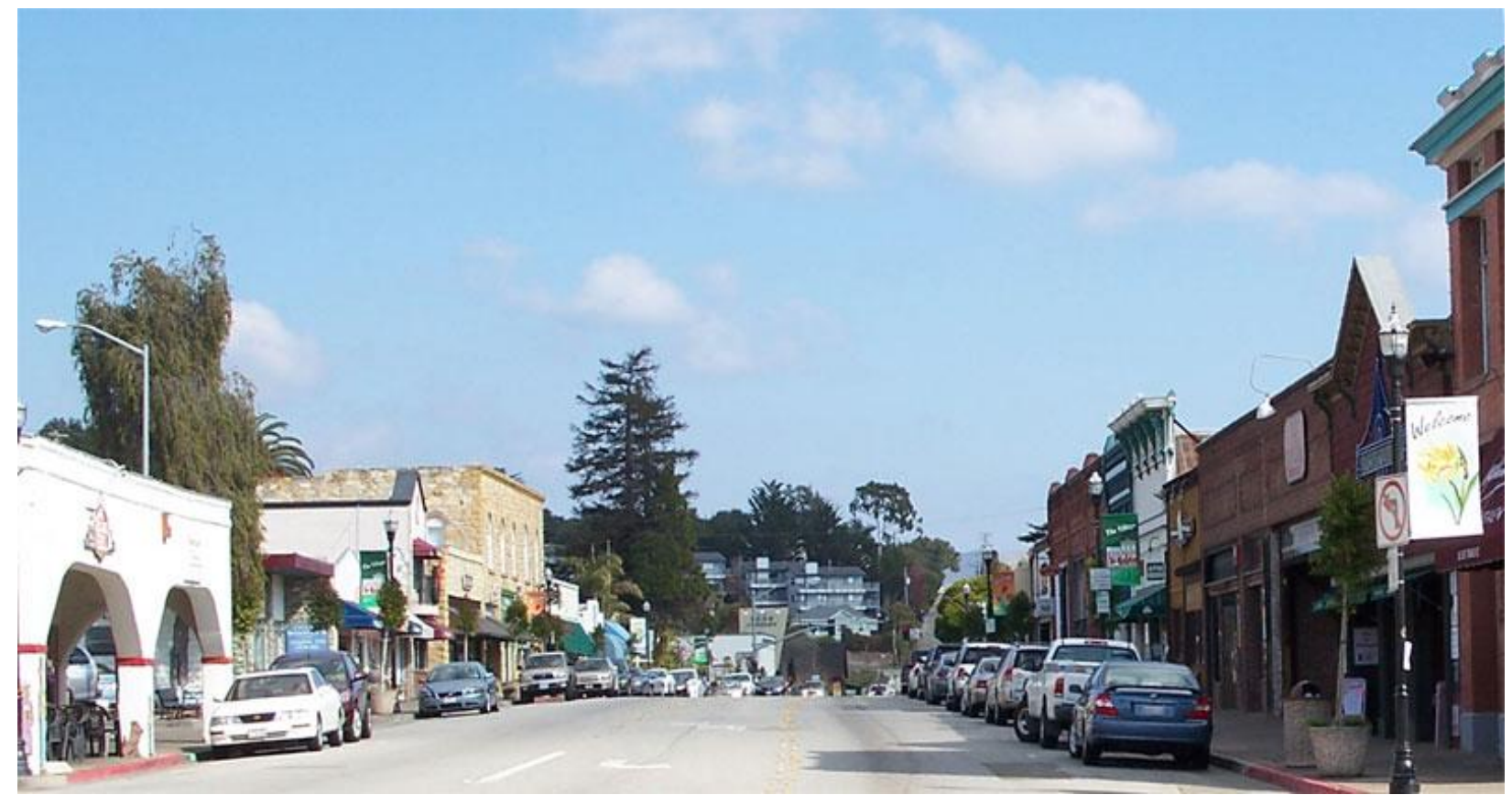

Figure 3 Village of Arroyo Grande, Branch Street, present day

The Village area is of great significance to the economic development of Arroyo Grande as it was the commercial core and center. By the turn of the twentieth century more permanent buildings were constructed out of brick and stone. These types of buildings are small in scale and done in Western and Italianate false-fronts and are usually located close to the property line and neighboring properties.

As the Village area continued to develop, so did the type of housing. Initially, housing consisted of mostly one story cottages for middle and working class families. A few larger homes were constructed for more affluent and prominent families including the Conrow Mansion (1887), the Paulding House (1889) and a two-story yellow rock house for the Rice family. Residences along Bridge Street were larger in size and located on larger lots, Most of the housing was characterized by wood frames and small front porches. Houses were modest in size and usually vernacular, Queen Anne, Italianate or Craftsman in style. These homes are significant to Arroyo Grande's development as a city because they show how the City's growth stemmed from agriculture. Additionally, these homes represent the City's early founders and are rare examples of early local residential construction methods. 


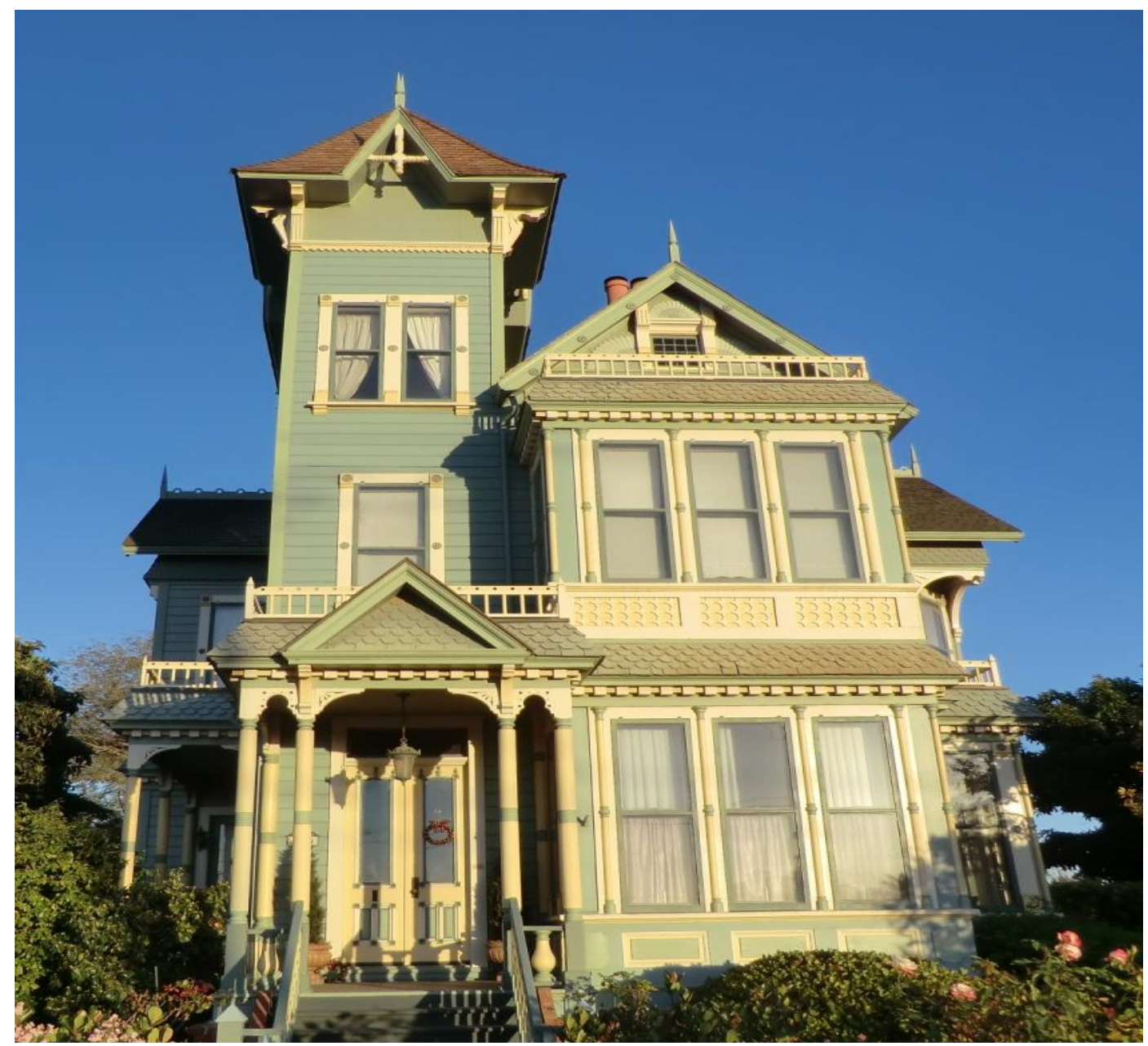

Figure 4 Conrow Mansion

As the population increased, so did the need for schools. The Santa Manuela Schoolhouse was built in 1867 and named after the wife of Francis Branch. One of the first teachers was Clara Edwards Paulding. An additional grammar school was constructed 1891 just south of the Village and burnt down in 1899. It was rebuilt in 1900 on the same site. A high school was constructed in 1906 on Crown Hill, located just above the Village. That brick school was later demolished in 1961.

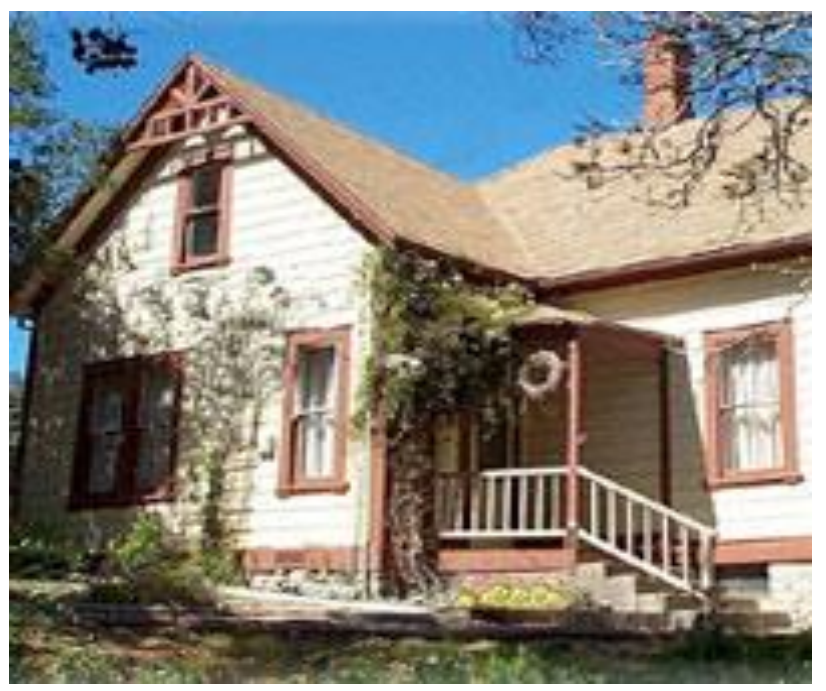

Figure 5 Paulding House 


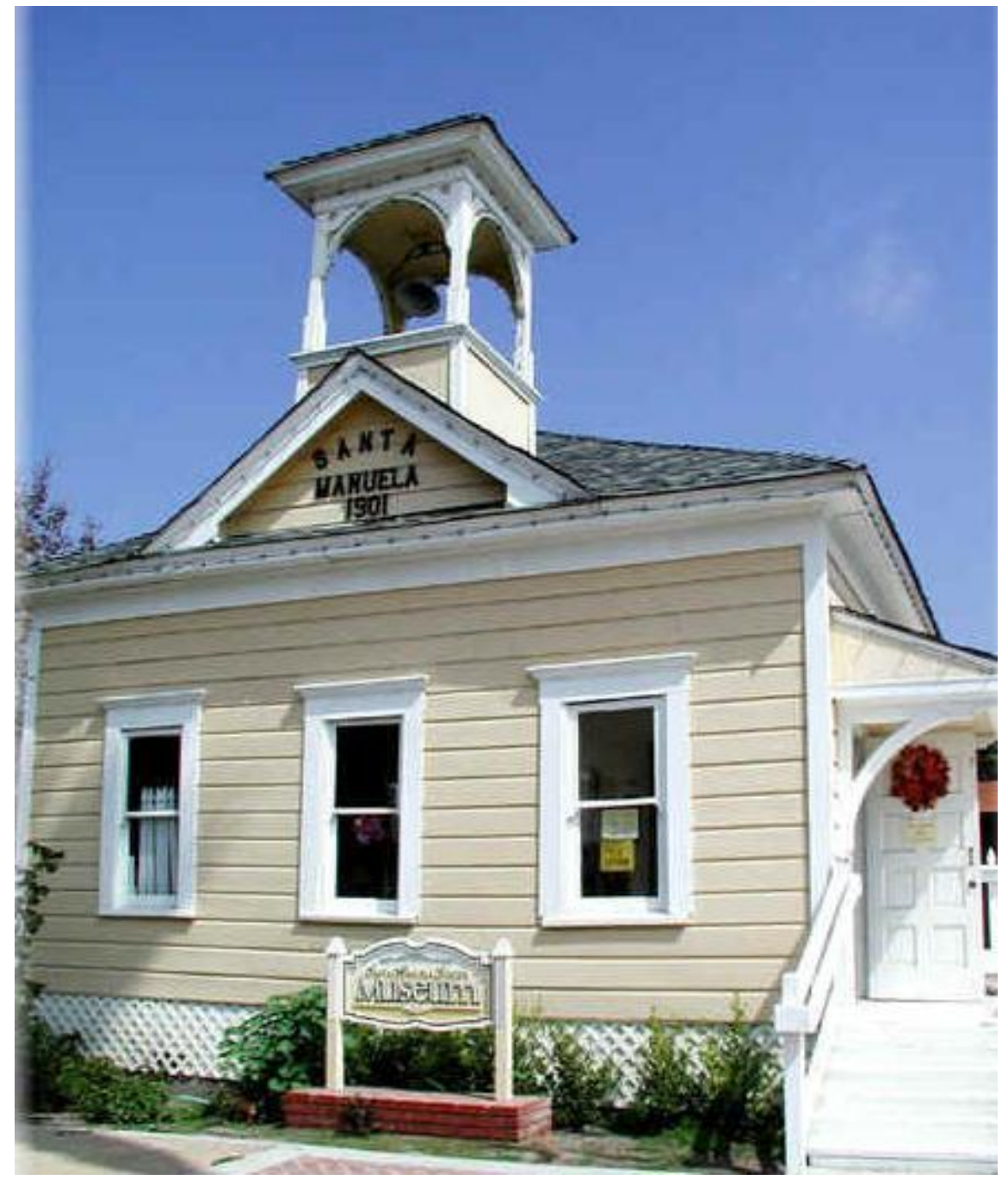

Figure 6 Santa Manuela School House

Other amenities were added to Arroyo Grande, including an automobile service station which was opened by Leo Brisco in the 1920s and a movie theatre in 1923. By 1931, dozens of new houses were constructed within the City, and cohesive neighborhoods began to emerge. The areas along Mason, Le Point, Nelson, Allen and Branch streets saw most of this development.

The end of World War II ushered in tremendous development, both in population and building technology. Significant commercial development occurred along East Grand Avenue as well as residential subdivisions occurring in the more western part of the City. Development was furthered by the car culture. As new types of buildings emerged so did the demolition and alterations of buildings with the mostly untouched Village area. This time period also ushered in a tremendous growth in the housing stock. New subdivisions sprang up all over the City as well as various types of multifamily housing. Most of the subdivisions built in the 1950s through the 1970 s still remains today. 


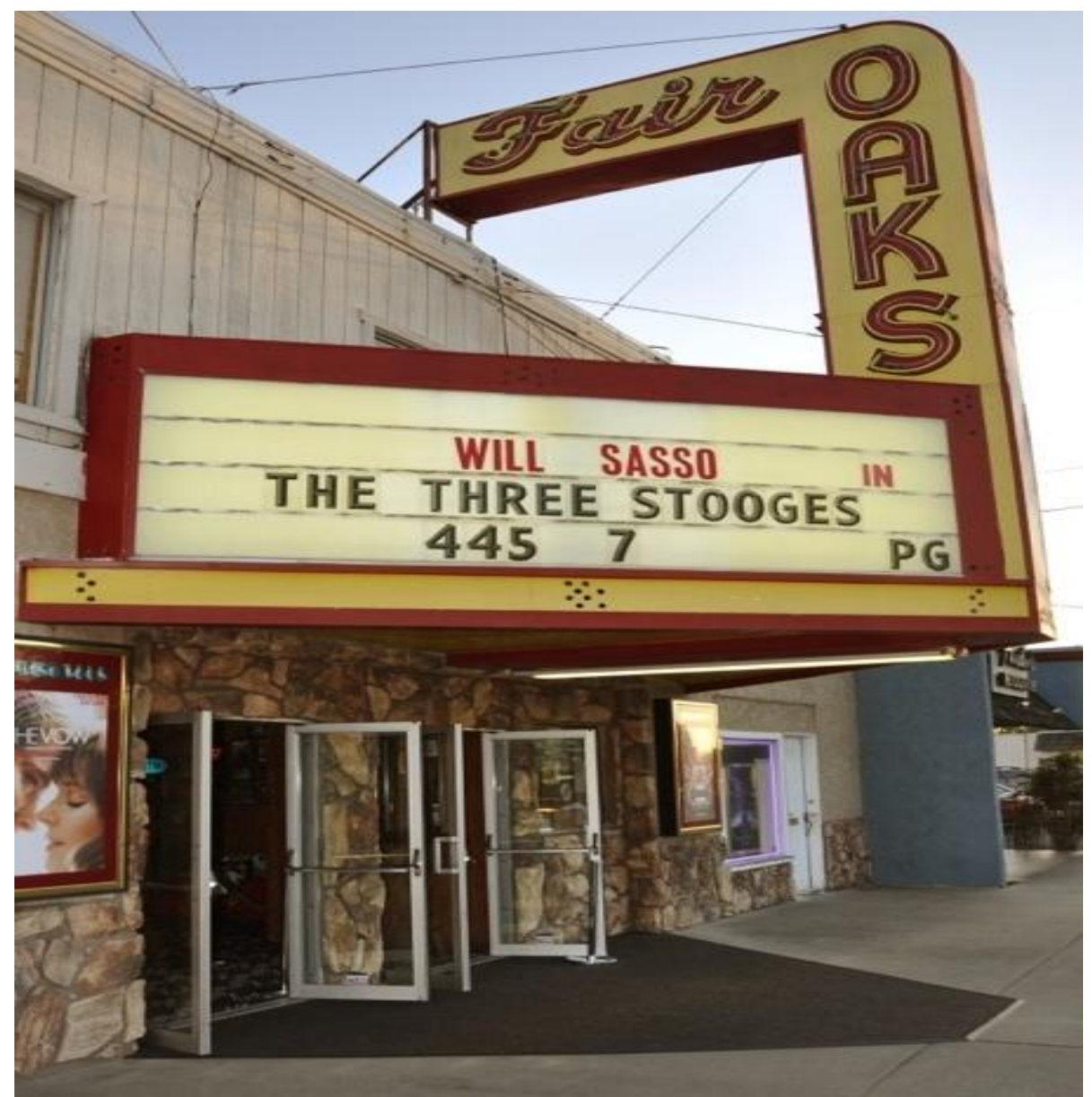

Figure 7 Fair Oaks Theatre

By the 1960s, the community had seen increased development and modernization. With this brought the threat of the loss of the Village core. Support over historic preservation grew with the formation of the South County Historical Society which was founded in 1978. Plans were made in 1966 to demolish the Village core and replace it with modern buildings. The plans to demolish the Village never came to fruition but it created within the City a need to preserve the City's historic core. This need to preserve has never been more urgent as only a small number of historic buildings remain within the Village core and the surrounding residential neighborhoods.

The unique character of Arroyo Grande has been shaped by over two hundred years of history, people and culture. This character is most evident in the Village area which still retains much of its original historic character while respecting the need for moving forward. This is also true for many of the neighborhoods directly surrounding the Village, some of the oldest remaining structures in Arroyo Grande. All of these structures collectively make Arroyo Grande what it is today: an eclectic historic city that is not afraid to show its love for the past while still maintaining connections to the present and future. 


\section{SUMMARY OF CURRENT AND PAST PRESERVATION EFFORTS:}

The City officially began showing interest in historic preservation as early as 1985 . This is when the first historic preservation document was drafted by the City. Since then, the number of preservation approaches and efforts has multiplied. Below is a list of the past and current preservation efforts the City has undertaken.

- 1985: first version of Design Guidelines for Arroyo Grande Village drafted (not formally adopted)

- 1985: March, informal "Historical Buildings and Sites Survey" conducted by the South County Historical Society

- 1991: informal historic resources survey (windshield survey)

- 1994: City Council formally adopted the Design Guidelines and Standards for the Historic Overlay District (D-2.4)

- 2003: Guidelines update adopted by City Council

- 2005: City Council approves the creation of a Historic Resources Committee

- 2005: City Council establishes a historic resources designation process

- 2006: Appointment of first Historic Resources Committee

- 2007: historic designation ordinance adopted

- 2008: Guidelines update adopted by City Council

- 2009: Guidelines update adopted by City Council

- 2011: Formal historic resources survey conducted by historic resources consultant

- 2012: City Council adopts Historic Context Statement

- 2013: City Council adopts Mills Act property tax abatement program

\section{Design Guidelines and Standards for the Historic Overlay District:}

This document has undergone five revisions since its inception in 1985. The document was formally adopted by the City Council in 1994 with the purpose of providing standards and guidelines for development in the Historic Overlay District (the Village). The document details the following six objectives:

- $\quad$ Safeguard the heritage of Arroyo Grande.

- Encourage public knowledge, understanding and appreciation of the City's past.

- Enhance the visual character of the City and the Village by preserving and promoting diverse and harmonious architectural styles and designs that reflect historic character and stages in the development of the City.

- Conserve valuable material and energy resources by continued use of the existing built environment.

- Protect property values and increase financial and economic benefits to the owners, businesses and residents of Arroyo Grande.

- Ensure that new construction and renovation of existing buildings are compatible with the historic character of the Village area and surrounding neighborhoods. 
It is important to note that there is a distinction between guidelines and standards. The document defines guidelines as: statements that indicate preference or principles indicated by descriptive statements including "should", "is encouraged", "is desired" and "may". Standards are more stringent and are defined as: statements indicated by language that is unequivocal and that prescribe minimum acceptable limits. Statements such as "shall", "is required" and "must" are standards.

According to staff, the current version of the Design Guidelines is widely utilized and extremely effective. Projects that fall under this document's purview are subject to design review by the Historic Resources Committee, the Architectural Review Committee or both. The committees take their work seriously and are committed to the objectives set forth in the document.

\section{Historic Resources Surveys:}

Of the surveys on hand, the City relies most heavily on the one conducted by historic preservation consultants Page \& Turnbull. This is because the survey was completed by professionals in the field of historic preservation. What has resulted from the surveys is data that can be used to designate resources. To date, the city has eleven locally designated resources, one of which is state registered and one of which is nationally registered.

\begin{tabular}{|l|c|}
\hline \multicolumn{1}{|c|}{ Name and Address or Location } & Year Designated \\
\hline Rice House- 734 Myrtle St. & 2013 \\
\hline Former City Hall 214 E. Branch St. & 2009 \\
\hline Conrad House 208 E. Branch St. & 2009 \\
\hline Residence- 145 W. Branch St. & 2008 \\
\hline Office- 139 W. Branch St. & 2008 \\
\hline Santa Manuela Schoolhouse & unknown \\
\hline Ruby's House- 134 S. Mason St. & unknown \\
\hline Heritage House 126 S. Mason St. & unknown \\
\hline Swinging Bridge & unknown \\
\hline Bridge Street Bridge & 1985 \\
\hline Paulding House 551 Crown Hill St. & 2009, California Register \\
\hline IOOF Hall- 128 Bridge St. & 1991, National Register \\
\hline
\end{tabular}

Table 1 Arroyo Grande Designation List

City staff is looking to have another survey conducted but is constrained by a lack of funding. The City is hoping for a broader survey that will include more properties as the formal survey only included 25 properties. Additionally, the City would like to look outside the immediate Village area and consider the City as a whole. Surveys play a vital role in the preservation of resources as identification is one of the first steps towards preservation. 


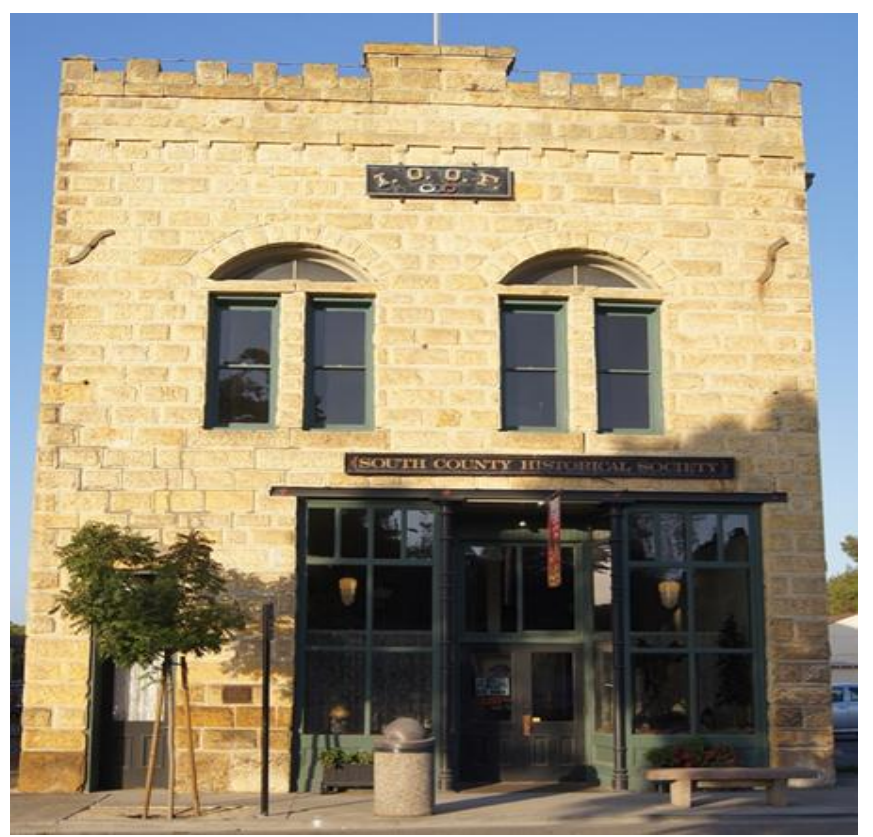

Figure 8 IOOF Hall, locally and nationally designated resource

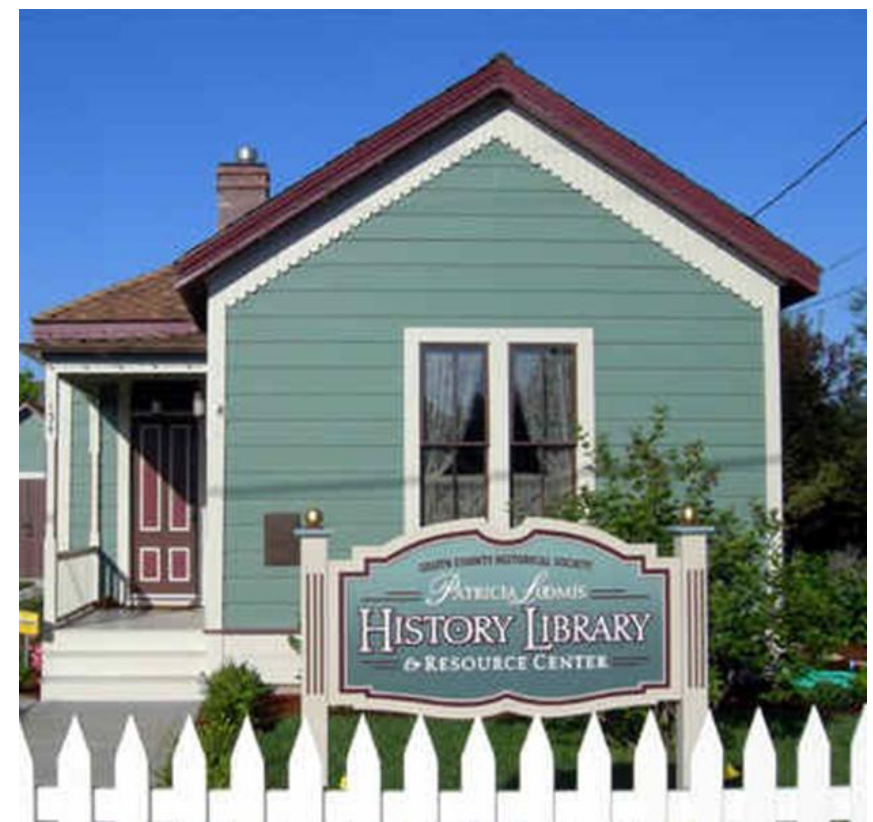

Figure 9 Patricia Loomis History Library, locally designated resource

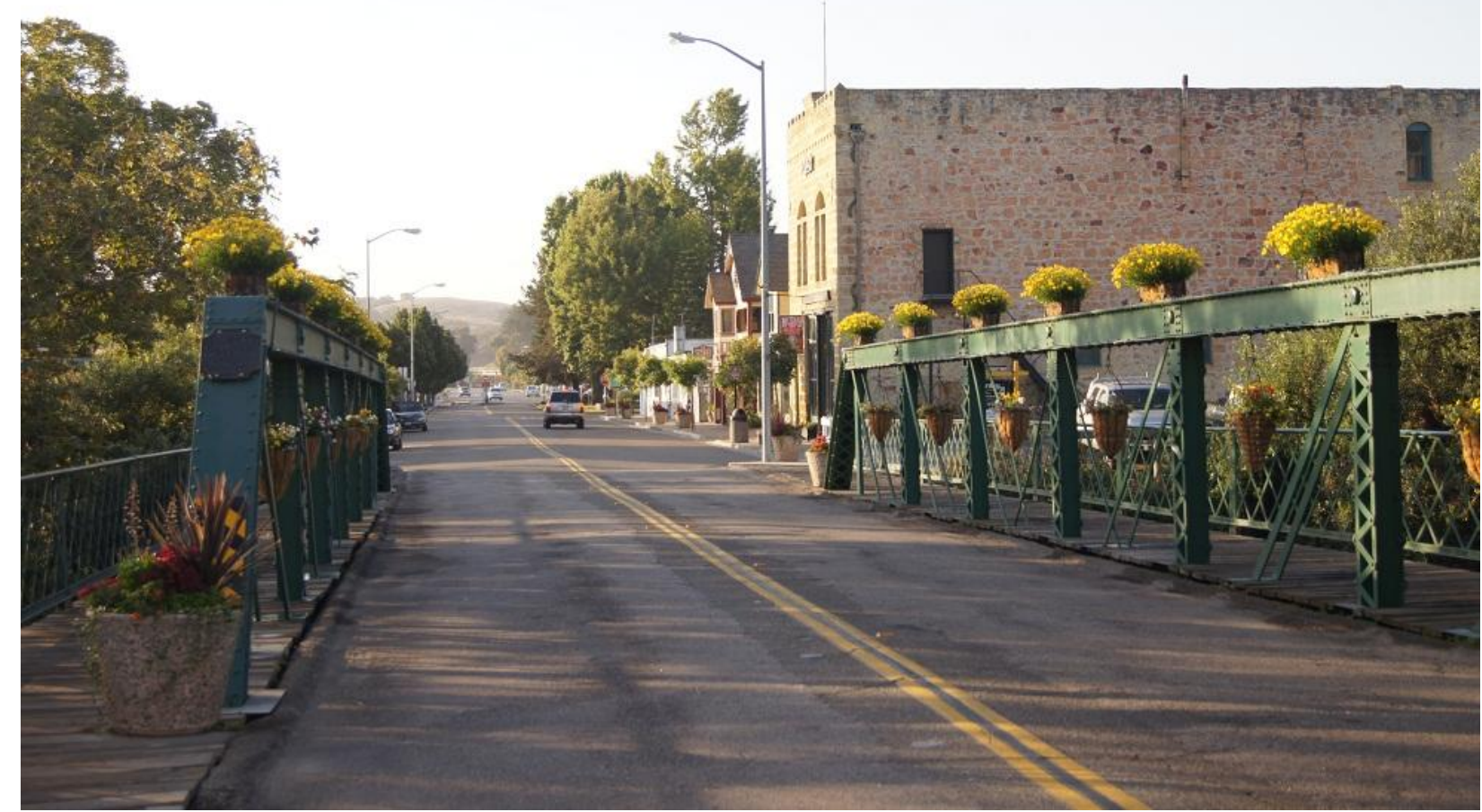

Figure 10 Bridge Street Bridge, locally designated resource 


\section{Historic Resources Committee:}

The formation of the Historic Resources Committee (HRC) came to fruition in order to assist staff, the Architectural Review Committee, Planning Commission and the City Council with future determinations regarding the designation and treatment of historic resources. Additionally, the HRC serves as an educational resource providing technical assistance and general information on the process and benefits of historic preservation to area residents and property owners.

Staff is pleased with the formation of a Historic Resources Committee. They believe the committee is an integral part in the preservation of resources as the committee was formed with the specific intent of preserving and protecting cultural and architectural resources of Arroyo Grande. Since its inception, the Committee has met regularly to evaluate projects and to also discuss the future of historic preservation in Arroyo Grande.

\section{Historic Designation Ordinance:}

One of the first tasks of the newly formed HRC was the creation of a historic designation ordinance. Staff worked closely with the Committee along with an outside consultant in the drafting of an ordinance. The purpose of the ordinance "is to promote the general welfare by providing for the identification, protection, enhancement, perpetuation and use of improvements, buildings, structures, signs, features, sites, places and areas within the City that reflect special elements of the City's historical, architectural, archaeological, cultural or aesthetic heritage for the following reasons:

1. To encourage public knowledge, understanding, appreciation, and use of the City's past;

2. To foster civic pride in the beauty and character of the city and in the accomplishments of its past;

3. To enhance the visual character of the City by encouraging new design and construction that complements the City's historical buildings;

4. To increase the economic benefits of historic preservation to the City and its inhabitants;

5. To protect property values within the City;

6. To identify as early as possible and resolve conflicts between the preservation of historic resources/districts and alternative land uses;

7. To conserve valuable material and energy resources by ongoing use and maintenance of the existing built environment."

Source: Arroyo Grande Municipal Code section 16.16.135

While both staff and the Committee are pleased to have a designation ordinance, they would like to see the designation criteria more in line with state and federal criteria. Additionally, staff would like to see the ordinance strengthened by making doing the wrong thing unattractive by imposing fees and penalties.

\section{Historic Context Statement:}

The context statement is a way for potential properties to be evaluated for historic significance. The context statement serves as the framework for the documentation and evaluation of historical resources. Properties are a part of the historic context of a city. Contexts describe the significant broad patterns of development in an area that may be represented by historic properties. 
Staff is pleased to have a completed context statement in their toolkit. It not only provides a better and more thorough understanding of the City's history, but it provides a complete understanding of how a property fits within the history of the City's development.

\section{Mills Act Property Tax Abatement Program:}

The Mills Act is a state law allowing cities to enter into contracts with the owners of historic structures. Such contracts require a reduction of property taxes in exchange for the continued preservation of the property. A property must first be designated as a resource in order to be considered for a contact.

The Mills Act is the latest preservation tool in Arroyo Grande's toolkit and has yet to be utilized by any residents. Despite its underutilization, City staff is confident that the contracts will prove to be quite attractive in incentivizing preservation. In fact, staff is working with the property owner of the recently locally designated Rice House and hopes to have the contract finalized soon.

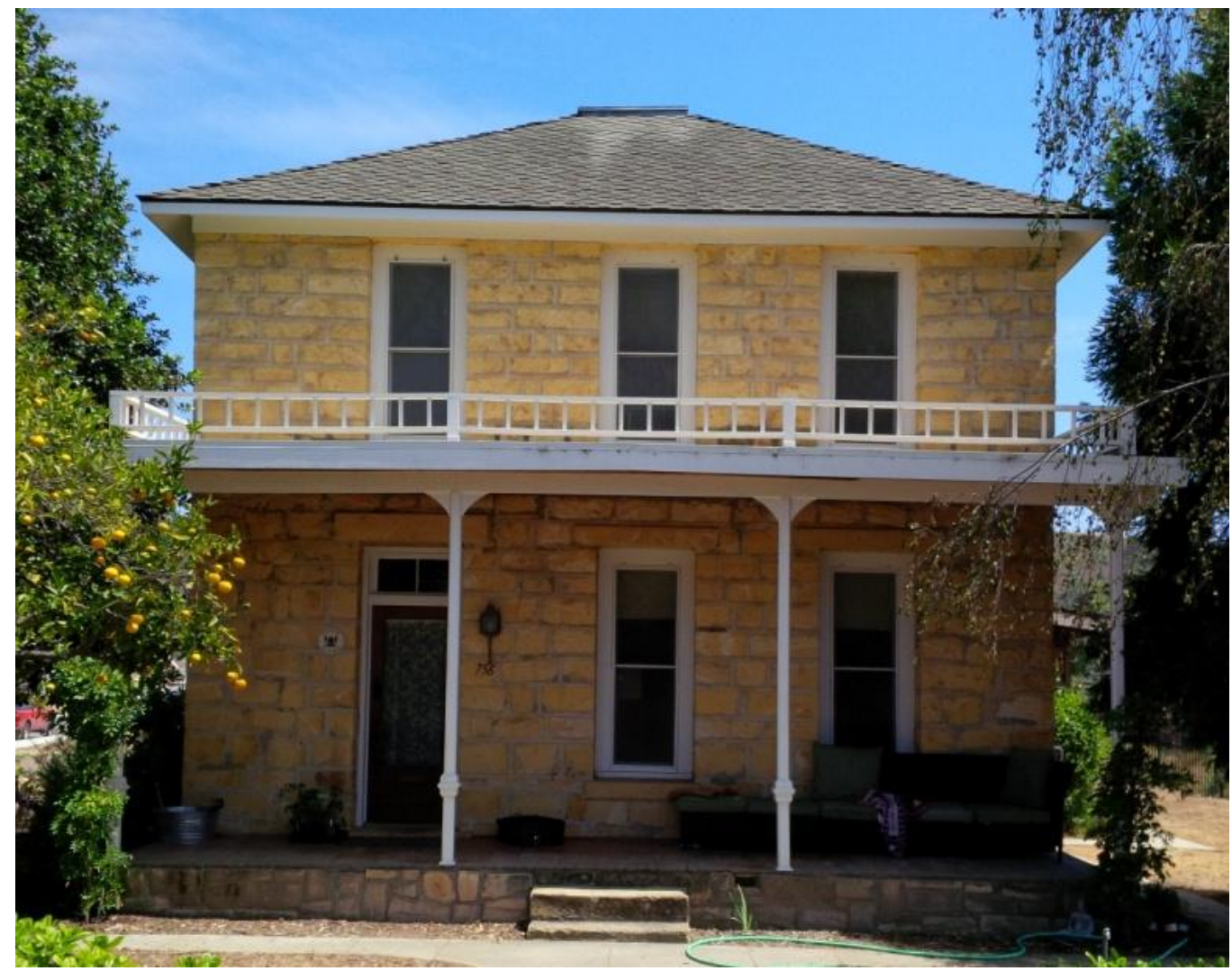

Figure 11 Rice House, locally designated resource and first Mills Act application (pending City Council approval) 


\section{COMPONENTS YET TO BE INCORPORATED INTO ARROYO GRANDE'S PRESERVATION APPROACH:}

\section{Education Program:}

One component that Arroyo Grande is lacking in their preservation toolkit is an education program. This component is extremely vital to the success of a preservation program. As discussed in the background report, an education program provides a way to get the word out on historic preservation. Both the research and interviews with preservation planners in other cities support the need for Arroyo Grande to incorporate an education program into their approach. Additionally, an education program informs the public on the various benefits of preservation and the programs the City offers. Educating the public on Arroyo Grande's preservation approaches is a way to garner public support. Public support is of the utmost importance as the public dictates how they want preservation to function in their city. A lack of this program may explain why participation in preservation is so low in Arroyo Grande.

\section{Recognition Program:}

A second component that Arroyo Grande is missing is a way to recognize property owners that are committed to and participate in historic preservation. Recognition is key for furthering a preservation program. Currently, the City does have a recognition program in place but has yet to use it. The program consists of providing a preservation award sign that they can display in the front yard of the awardee for one month. This sign is awarded by the City Council who makes a decision based on a recommendation from the Historic Resources Committee. The Committee chooses one property owner based on property owner's commitment to preservation.

Possessing a working and well utilized recognition program helps to ensure the success and promotion of historic preservation in cities. According to preservation planner Christine Nguyen from the City of Anaheim, providing recognition not only garners more support for preservation and helps to get the word out, but it also helps improve neighborhoods. Ms. Nguyen has seen improvements of whole neighborhoods when Mills Act plaques are displayed on participating properties.

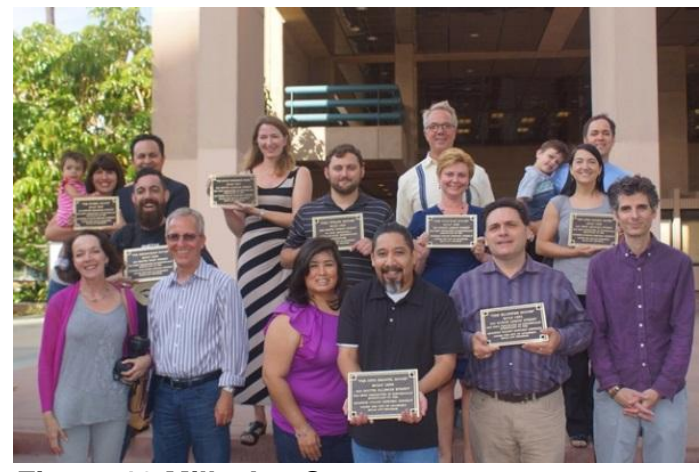

Figure 12 Mills Act Contract Participants receiving their recognition plaques, City of Anaheim

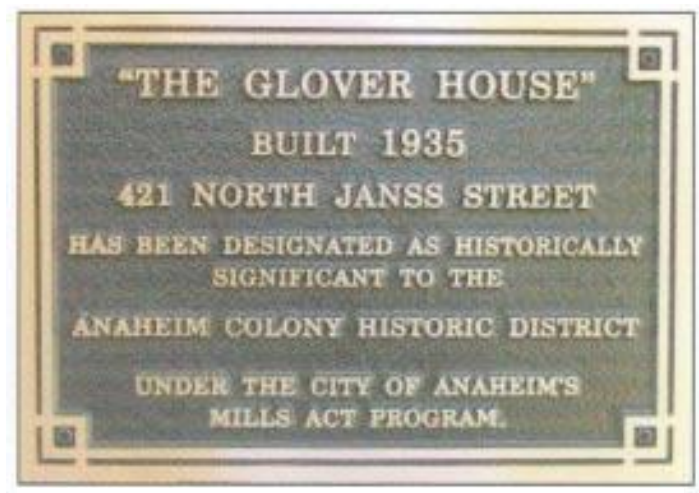

Figure 13 Mills Act Plaque, City of Anaheim 


\section{THE CITY'S HISTORIC RESOURCES SURVEYS:}

Since the beginning of historic preservation in Arroyo Grande, three surveys have been conducted; one in 1985, a second in 1991 and another in 2011. The 1985 survey was an informal survey conducted by the South County Historical Society. The 1985 survey yielded 113 structures "that may have significant local significance". This informational survey, while it did not produce any designations, did lay the foundation for future surveys. The second survey was conducted in 1991 by a City Intern. This once-over windshield survey provided a broad overview of potential resources within the City. Its main purpose was to inform the City's Design Guidelines for the Historic Overlay District. The survey focused on the Village core and the residential neighborhoods directly surrounding the Village. This survey looked at 113 structures but did not yield any official designations as it was not adopted by City Council. It was this survey that served to inform the 2011 survey.

The 2011 survey was a professional level intensive survey conducted by consultants Page and Turnbull. The consultants looked at a total of 25 properties and concluded that 13 of them possessed some historical significance.

2011 Survey Results: Potentially Significant Buildings

Address

215 E. Branch St.

123-131 E. Branch St.

114-116 W. Branch St.

118-124 W. Branch St.

100 E. Branch St.

112 E. Branch St.

118-120 E. Branch St.

201 E. Branch St.

$404 \mathrm{E}$. Branch St.

$415 \mathrm{E}$. Branch St.

$211 \mathrm{E}$. Branch St.

133 E. Branch St.

101 W. Branch St.

103 W. Branch St.

124-126 E. Branch St.

214 E. Branch St.

145 W. Branch St.

Table 22011 Survey results

A reason only one professional survey was conducted is due to a lack of funding. One way the City can help secure funding for future surveys and other preservation work is by becoming a Certified Local Government (CLG). Obtaining CLG status is achieved by working with the State to ensure the City meets the program requirements. The CLG program encourages local governments in the identification, evaluation, registration and preservation of historic properties. Grant money is provided to cities to help them in their preservation endeavors.

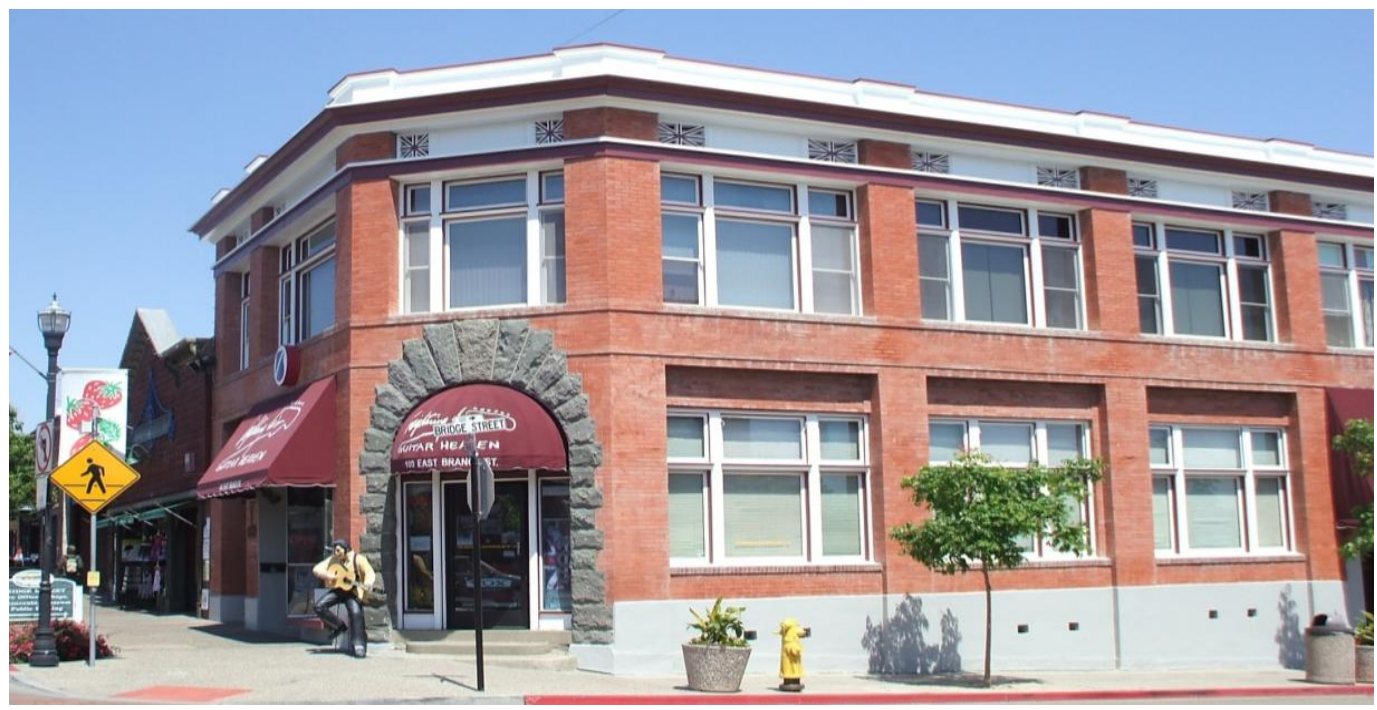

Figure 14101 W. Branch Street, potentially significant resource 


\section{HISTORIC PRESERVATION ISSUES, GOALS AND ACTIONS:}

The Historic Resources Committee identified issues related to historic preservation in Arroyo Grande. The identification of issues is what serves to inform the goals and action of future preservation planning in the City. The following is a list of issues, goals and actions identified by the Committee:

Issue: The lack of an educational outreach program

1. Goal: Increase the public recognition and awareness of Arroyo Grande's historic resources through a strategic educational outreach program.

\section{Actions:}

a. Develop a set of educational brochures that outlines Arroyo Grande's historic preservation programs, the benefits of historic preservation, the Mills Act program and the Secretary of the Interiors Guidelines and Standards for the treatment of historic structures.

b. Coordinate with citywide events such as the farmers market, Harvest Festival and Strawberry Festival to set up a booth to disseminate information related to Arroyo Grande's historic preservation program.

c. Coordinate with the City's information technology department to run information related to historic preservation the City's public access channel and the City website.

d. Create a Facebook page dedicated to historic preservation in Arroyo Grande (example: see appendix 1).

e. Facilitate communication between the Historic Resources Committee and other decision making bodies in Arroyo Grande further promote historic preservation to a wider audience.

f. Facilitate events during May, national historic preservation month and national bike month. Events could include a historic bike tour.

g. Create and facilitate a Mills Act workshop.

Issue: Historic resource identification and designation, and expansion of the information base on City history

2. Goal: Conduct a systematic citywide survey for potentially historic structures, designate and protect accordingly.

\section{Actions:}

a. Create a systematic plan to survey the City (see background report for discussion of survey types).

b. Contract with a qualified consultant to conduct an intensive-level survey of the City according to the systematic plan.

c. Develop a process for the regular re-survey and update of previous survey work (every 5-10 years). 
d. Incorporate all resources determined eligible for local designation into the City's Historic Resources Inventory List.

Issue: Design guidelines and technical assistance

3. Goal: Develop and create design guidelines and technical assistance documents based off the Secretary of the Interior's Standards and Guidelines for the treatment of historic structures.

\section{Actions:}

a. Contract with an expert in the field of historic preservation to create/author design guidelines based on the Secretary of the Interiors Guidelines and Standards for historic preservation.

b. Create informational brochures to disseminate to the public containing information on how historic materials (bricks, wood, windows, etc) should be treated according to the Secretary of the Interior.

c. Facilitate regular workshops with property owners and local contractors to provide information on how to treat historic properties.

Issue: Recognition of the preservation of historic structures

4. Goal: Develop and create a program for recognition of the preservation of historic structures

\section{Actions:}

a. Create a plaque program for those structures that have entered into Mills Act contracts.

b. Create a plaque program for those structures that have been locally designated.

c. Designate one structure each year as an example of exemplary preservation. Commemorate with an award gifted at a City Council meeting.

d. Recognize those structures that have been designated as historic on the City's website.

e. Create a Preservation Press quarterly newsletter that provides the latest information on preservation happenings in Arroyo Grande, including a section dedicated to recognizing those who have entered into Mills Act contracts, recently designated their properties and those who won the award for exemplary preservation.

Issue: Protection of historic resources in Arroyo Grande

5. Goal: Update the Arroyo Grande historic designation ordinance to be more in line with the standards set forth by the Office of Historic Preservation

\section{Actions:}

a. Review Technical Assistance Bulletin \#14- Drafting and Amending Historic Preservation Ordinances by the Office of Historic Preservation.

b. Review local ordinances implemented in other California cities and speak with planners regarding the successes and challenges faced. 
c. Direct staff and the Historic Resources Committee to work together to create a list of what they want the ordinance to accomplish.

d. Work with other City departments and committees to understand how to properly preserve structures in Arroyo Grande.

Issue: Consensus building among elected officials, the general public, business owners and property owners

6. Goal: Conduct consensus building workshops and outreach to ensure the values of the community are reflected in the updated ordinance

\section{Actions:}

a. Instruct staff to work with City Council and the Historic Resources Committee to establish a set of goals that the ordinance will strive to meet.

b. Provide the City Council and Historic Resources Committee with training on Technical Assistance Bulletin \#14 Drafting and Amending Historic Preservation Ordinances by the Office of Historic Preservation.

c. Facilitate meetings based on neighborhoods (Village Core, Village Mixed Use, Village Residential, etc) to establish a community advisory group. Conduct broad outreach to ensure a wide variety of views is represented.

Issue: Creating more clout and resources for Arroyo Grande's preservation approaches

7. Goal: Arroyo Grande obtaining Certified Local Government (CLG) status

\section{Actions:}

a. Conduct research on the application process for becoming a CLG.

b. Direct City staff/consultant to work with the California Office of Historic Preservation on filling out the necessary applications and paper work to obtain CLG status. 